\title{
Experimental Study and Proposal to Improve the EWM Design of Cold-Formed Steel Lipped Channel Columns with Circular Holes under Axial Compression
}

\author{
Xingyou Yao \\ School of Civil Engineering and Architecture, Nanchang Institute of Technology, Nanchang 330000, Jiangxi, China \\ Correspondence should be addressed to Xingyou Yao; yaoxingyoujd@163.com
}

Received 7 September 2021; Accepted 23 November 2021; Published 10 December 2021

Academic Editor: Tomasz Trzepieciński

Copyright ( $\odot 2021$ Xingyou Yao. This is an open access article distributed under the Creative Commons Attribution License, which permits unrestricted use, distribution, and reproduction in any medium, provided the original work is properly cited.

\begin{abstract}
The cold-formed steel (CFS) lipped channel section with circular holes has been widely used in low-rise and multistory building structures as the column. However, the circular hole in the web makes the lipped channel column become susceptible to buckle. A total of 54 CFS lipped channel axial compression columns with and without circular holes were used to study the buckling behavior and the effective width design method. The interaction of the local buckling and the distortional buckling were observed for the short and intermediate columns, while the slender columns were controlled by the interaction of the local buckling, distortional buckling, and flexural buckling or flexural-torsional buckling. The experimental failure loads were gradually decreased with the increase in the diameter of the circular hole for the specimens with the same section. The failure loads of the specimens with two holes were lower than those of the specimens with one hole with same section and same diameter of holes. Then, the experimental results were used to validate a nonlinear finite element model (FEM) previously developed by the authors. The validated FEM was subsequently used to obtain additional 36 numerical failure results concerning the effects of the length, the section, and the diameter and the number of the circular holes. Furthermore, the proposal to calculate the distortional buckling coefficient of the CFS lipped channel section with circular holes were put forward based on numerical analysis considering the reduction of effect of holes. Finally, a proposal to improve the effective width method (EWM) design approach for CFS lipped channel sections with circular holes under axial compression was presented. The comparisons between experimental and numerical capacities and their calculations provided by the proposed EWM design method illustrate a great application of the proposed approach.
\end{abstract}

\section{Introduction}

The CFS lipped channel sections with holes in the web have been extensively used in low-rise and multistory building constructions as walls and floors. Although the hole in the web makes conduits to be easy to install, the presence of the holes can decrease the cross-sectional areas, stiffness, and ultimate capacities of CFS members.

The experiment of short columns with circular holes revealed that the failure loads reduced with the increase in the ratio of the diameter of hole to the height of web [1]. The short and intermediate CFS lipped channel columns with slotted holes conducted by Moen and Schafer [2] indicated that the presence of slotted holes resulted in a slight decrease in the failure loads and change in the failure modes of some specimens. The axial compression test of CFS intermediate lipped channel columns with circular holes [3] indicated that the compression stress of the plate strip adjacent to the circular hole was higher than that of other parts of the web. The experiments and numerical analysis of the intermediate lipped channel columns with slotted holes carried out by Yao et al. [4] displayed the distortional buckling resulted from the presence of holes. The test and finite element analysis for CFS structural members with perforations subjected to compression loading indicated that the ultimate failure load varied greatly because of the presence of perforations $[5,6]$. The distortional buckling 
was observed for all CFS intermediate C-shape columns with slotted holes [7]. The influence of spacing, size, and shape of the hole on the distortional buckling of CFS channel columns was simulated using ANSYS software [8]. Guo and Yao [9] conducted the test of the intermediate CFS lipped channel columns with rectangular holes under axial compression and recommended a simplified EWM-based design method. Dung et al. [10] performed the experiments on slender channel columns with circular holes and observed that all specimens with holes had a slightly decrease in the flexural-torsional buckling and the ultimate capacities than the specimens without holes. Moen and Schafer [11] recommended a direct strength method to predict the ultimate strength of CFS sections with holes. With the basics of the direct strength method presented by Moen and Schafer, Yao and Rasmussen [12] proposed a modified direct strength method design formula according to the numerical analysis.

The calculation approach of critical buckling capacities or buckling coefficients for CFS sections with holes under axial compression has been also studied by some researchers. The simplified methods were provided by Moen and Schafer to calculate the critical local buckling capacity [13], critical distortional buckling capacity, and global buckling capacity [14] of the CFS section with holes based on theoretical and numerical analyses. Zhou and $\mathrm{Yu}$ [15] recommended an equivalent modulus method to calculate the critical buckling capacity of the CFS column with slotted holes. Yao et al. [16] developed an modified design formula of the distortional buckling coefficient for CFS lipped channel members with slotted holes under axial compression.

In terms of the design method for CFS lipped channel sections with circular holes, Chinese code has no relevant design provision [17]. American Iron and Steel Institute (AISI) [18] provides the effective width design method which is only suitable to channel sections with small circular holes. The modified direct strength method is also presented in AISI considering the effect of holes, but the elastic buckling capacity should be predicted by the complicated formula or using finite element method.

As provided previously an overview of buckling behaviors and design methods of CFS lipped channel sections with holes, limited work has been reported on the lipped channel sections with large circular holes. Hence, the main objective of this work is to report 54 new buckling experiments of CFS lipped channel sections with circular holes in the web under axial compression. A developed nonlinear FEM was validated against the experimental results in terms of failure buckling modes and failure loads. The failure loads of the additional CFS lipped channel sections with circular holes were further analyzed by means of validated FEM concerning the effects of the length, the section, and the size and number of holes. The proposal of calculation approach of the distortional buckling coefficient was presented for CFS lipped channel sections with circular holes considering the effect of the circular hole. Finally, an EWM-based design approach was presented and the design capacities were compared against both the experimental and numerical results.

\section{Test Programme}

2.1. Test Specimens. 54 CFS lipped channel columns including 42 columns with circular holes and 12 columns without hole were tested under axial compression. Figure 1 illustrates the definitions of geometric parameters of test members. Two lipped channel sections (C80 and C90) with the nominal wall thickness of $0.8 \mathrm{~mm}$ were selected to test. For each lipped channel section, three different nominal member lengths $(500,1000$, and $2000 \mathrm{~mm}$ ) were prepared. Figure 2 depicts the location and spacing of the circular holes in the web. The ratios of diameters of the circular holes to the height of the web $(d / h)$ were $0.3,0.5$, and 0.7 . The specimens with a nominal length of $500 \mathrm{~mm}$ had one circular hole. The specimens with a nominal length of $1000 \mathrm{~mm}$ had one or two circular holes. There were three circular holes in the web for the specimens with a nominal length of $2000 \mathrm{~mm}$. Figure 3 shows the label rule of the test specimens. For example, C8010-2H5-2 defines the specimen as follows: $\mathrm{C}$ means a lipped channel section; 80 indicates that the nominal height of the web is $80 \mathrm{~mm}$; $2 \mathrm{H} 5$ represents that the section has two circular holes and the ratio of the diameter of the circular hole to the height of the web is $0.5 ; 2$ represents the sequence number of the same specimen. The nominal and measured cross-sectional dimensions and the lengths of all specimens are given in Table 1.

2.2. Material Tensile Coupon Tests. The zinc-coated steel plate with grade Q550 was selected to produce the test specimens. 3 tensile coupons shown in Figure 4(a) were performed to obtain the material properties of the specimens based on Chinese code "Tensile tests of metallic materials Part 1: test methods at room temperature" (GB/T228.12010) [19]. The failure modes of 3 tensile coupons are shown in Figure 4(a). The stress-strain curves of coupon tests are illustrated in Figure 4(b). The average material properties obtained from the coupon tests including the $0.2 \%$ proof stress $\left(f_{0.2}\right)$, the elastic Young's modulus $(E)$, the ultimate tensile strength $\left(f_{\mathrm{u}}\right)$, and the elongation after fracture $(\varepsilon)$ were $602 \mathrm{~N} / \mathrm{mm}^{2}, 2.16 \times 10^{5} \mathrm{~N} / \mathrm{mm}^{2}, 615 \mathrm{~N} / \mathrm{mm}^{2}$, and $7.67 \%$, respectively. The proof stress $\left(f_{0.2}\right)$ was used as the yield strength in finite element analysis and calculation of ultimate capacities of specimens.

2.3. Initial Geometric Imperfection Measurements. The initial geometric imperfections have a great influence on the buckling behavior, failure mode, and failure load of CFS members. Therefore, the initial geometric imperfections of all columns specimens along the longitudinal direction were measured. The deviations along four longitudinal lines at points 1, 2, 3, and 4 in the cross section depicted in Figure 5 are adopted to get the amplitudes of four different initial imperfections including the initial local geometric imperfection, the initial distortional geometric imperfection, the initial overall geometric imperfection about the cross-sectional weak axis, and the initial overall geometric imperfection about the cross-sectional strong axis, respectively. The intervals of longitudinal measure points are 50,100, and 

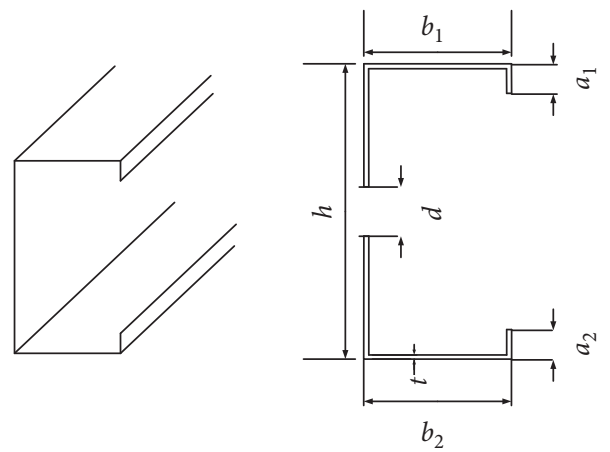

FIGURE 1: Section definition of CFS lipped channel columns with circular holes.

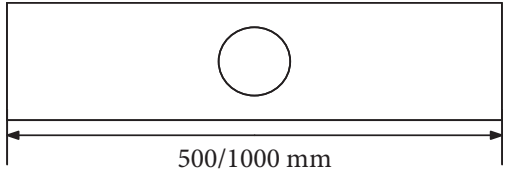

(a)

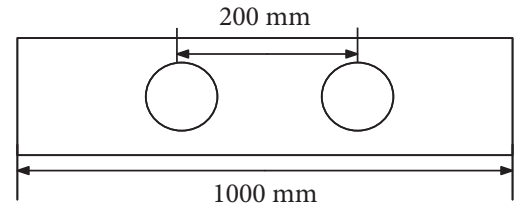

(b)

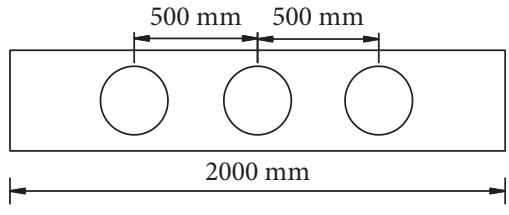

(c)

Figure 2: Location and spacing of circular holes in the web. (a) Web with one circular hole. (b) Web with two circular holes. (c) Web with three circular holes.

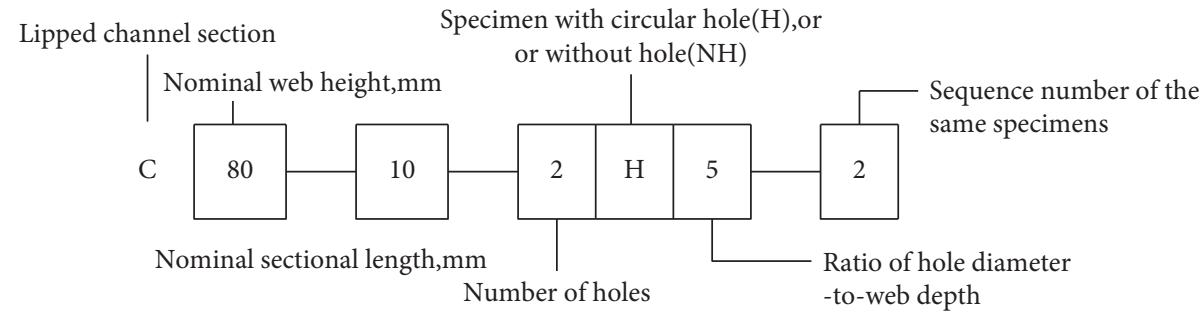

Figure 3: Label rule of the specimen.

$200 \mathrm{~mm}$ for columns with lengths 500, 1000, and $2000 \mathrm{~mm}$, respectively. The initial geometric imperfections of the specimen C80-05-1H3-1, C80-10-1H3-1, and C80-20-3H3-1 are depicted in Figure 6 . The initial geometric imperfections of other specimens can be found in reference [20]. The measured initial imperfections indicated that the initial distortional imperfections were larger than the initial local imperfections and initial overall imperfections. The measured maximum magnitudes $\left(\Delta_{\max }\right)$ of the initial geometric imperfection of all test specimens are listed in Table 1.

2.4. Test Setup and Operation. All the specimens were compressed by using a frame system and a $500 \mathrm{kN}$ hydraulic Jack, as shown in Figure 7 [21]. The upper actuator and lower plate were fitted with $250 \mathrm{~mm} \times 200 \mathrm{~mm} \times 6 \mathrm{~mm}$ thick steel plate. The specimens were put on the steel plates directly. The LVDTs (linear variable displacement transducers) and strain gauges were used to measure the deformation and strain of the specimens during the loading process, as shown in Figure 8. Figures 8(a) and 8(b) show the LVDT positions for specimens with circular holes and without hole, respectively. The measured positions of strain gauges are depicted in
Figures 8(c) and 8(d) for specimens with circular holes and without hole, respectively. A LVDT is vertically set at top end plate to record the axial shorten displacement of test specimens. A data acquisition system was used to automatically record the axial load, deformation, and strain of test specimens at regular intervals.

\section{Test Results and Analysis}

3.1. Failure Modes. The failure modes of all 54 specimens are shown in Table 2, where L, D, F, and FT represent local buckling, distortional buckling, flexural buckling, and flexural-torsional, respectively. The failure modes listed in Table 1 indicates that the specimens with a length of $500 \mathrm{~mm}$ and $1000 \mathrm{~mm}$ were controlled by interaction of local buckling and distortional buckling, and the specimens with a length of $2000 \mathrm{~mm}$ failed with interaction of local buckling, distortional buckling, and overall buckling.

For the specimens with the length of 500 and $1000 \mathrm{~mm}$, the local buckling of web (Figures 9(a) and 10(a)) and flange (Figure 9(b)) was observed firstly during loading. The distortional buckling was observed sequentially (Figures 9(c) 
TABLE 1: Nominal and measured dimensions of specimens.

\begin{tabular}{|c|c|c|c|c|c|c|c|c|c|c|c|c|}
\hline \multirow[b]{2}{*}{ Specimen } & \multicolumn{5}{|c|}{ Nominal dimensions } & \multicolumn{6}{|c|}{ Measured dimensions } & \multirow[b]{2}{*}{$\begin{array}{c}\text { Maximal initial } \\
\text { imperfection } \Delta_{\max }(\mathrm{mm})\end{array}$} \\
\hline & $\begin{array}{c}L \\
(\mathrm{~mm})\end{array}$ & $\begin{array}{c}h \\
(\mathrm{~mm})\end{array}$ & $\begin{array}{c}b \\
(\mathrm{~mm})\end{array}$ & $\begin{array}{c}a \\
(\mathrm{~mm})\end{array}$ & $\begin{array}{c}t \\
(\mathrm{~mm})\end{array}$ & $\begin{array}{c}L_{1} \\
(\mathrm{~mm})\end{array}$ & $\begin{array}{c}h_{1} \\
(\mathrm{~mm})\end{array}$ & $\begin{array}{c}b_{1} \\
(\mathrm{~mm})\end{array}$ & $\begin{array}{c}b_{2} \\
(\mathrm{~mm})\end{array}$ & $\begin{array}{c}a_{1} \\
(\mathrm{~mm})\end{array}$ & $\begin{array}{c}a_{2} \\
(\mathrm{~mm})\end{array}$ & \\
\hline $\begin{array}{l}\text { C80-05- } \\
\mathrm{NH}-1\end{array}$ & \multirow{8}{*}{500} & \multirow{8}{*}{80} & \multirow{8}{*}{60} & \multirow{8}{*}{10} & \multirow{8}{*}{0.80} & 499.56 & 78.31 & 59.03 & 60.03 & 10.02 & 9.94 & 0.512 \\
\hline $\begin{array}{l}\text { C80-05- } \\
\text { NH-2 }\end{array}$ & & & & & & 499.65 & 79.12 & 59.21 & 59.11 & 10.05 & 10.03 & 0.587 \\
\hline $\begin{array}{l}\text { C80-05- } \\
\text { 1H3-1 }\end{array}$ & & & & & & 499.75 & 79.56 & 59.46 & 58.97 & 9.78 & 10.11 & 0.487 \\
\hline $\begin{array}{l}\text { C80-05- } \\
1 \mathrm{H} 3-2\end{array}$ & & & & & & 499.55 & 79.41 & 59.23 & 60.04 & 9.86 & 9.77 & 0.716 \\
\hline $\begin{array}{l}\text { C80-05- } \\
1 \mathrm{H} 5-1\end{array}$ & & & & & & 499.25 & 79.38 & 59.79 & 59.42 & 9.82 & 9.86 & 0.674 \\
\hline $\begin{array}{l}\text { C80-05- } \\
1 \mathrm{H} 5-2\end{array}$ & & & & & & 499.65 & 78.11 & 59.32 & 59.44 & 10.02 & 9.91 & 0.575 \\
\hline $\begin{array}{l}\text { C80-05- } \\
1 \mathrm{H} 7-1\end{array}$ & & & & & & 499.91 & 79.26 & 59.82 & 58.97 & 9.87 & 9.89 & 0.697 \\
\hline $\begin{array}{l}\text { C80-05- } \\
1 \mathrm{H} 7-2\end{array}$ & & & & & & 499.72 & 79.11 & 59.48 & 59.64 & 9.92 & 9.71 & 0.656 \\
\hline $\begin{array}{l}\text { C80-10- } \\
\text { NH-1 }\end{array}$ & \multirow{14}{*}{1000} & \multirow{14}{*}{80} & \multirow{14}{*}{60} & \multirow{14}{*}{10} & \multirow{14}{*}{0.8} & 1000.10 & 79.22 & 58.88 & 60.03 & 9.97 & 10.23 & 0.682 \\
\hline $\begin{array}{l}\text { C80-10- } \\
\text { NH-2 }\end{array}$ & & & & & & 1000.20 & 79.77 & 58.99 & 59.15 & 10.15 & 9.86 & 0.758 \\
\hline $\begin{array}{l}\text { C80-10- } \\
1 \mathrm{H} 3-1\end{array}$ & & & & & & 1000.10 & 79.53 & 59.51 & 59.04 & 10.12 & 9.24 & 1.091 \\
\hline $\begin{array}{l}\text { C80-10- } \\
\text { 1H3-2 }\end{array}$ & & & & & & 999.90 & 79.550 & 58.73 & 59.39 & 9.55 & 10.22 & 0.753 \\
\hline $\begin{array}{l}\text { C80-10- } \\
1 \mathrm{H} 5-1\end{array}$ & & & & & & 1000.00 & 79.44 & 59.22 & 58.33 & 10.12 & 10.03 & 1.015 \\
\hline $\begin{array}{l}\text { C80-10- } \\
1 \mathrm{H} 5-2\end{array}$ & & & & & & 999.90 & 79.40 & 59.93 & 59.30 & 9.58 & 9.42 & 1.022 \\
\hline $\begin{array}{l}\text { C80-10- } \\
1 \mathrm{H} 7-1\end{array}$ & & & & & & 1000.00 & 78.99 & 59.55 & 60.09 & 9.07 & 9.94 & 1.026 \\
\hline $\begin{array}{l}\text { C80-10- } \\
1 \mathrm{H} 7-2\end{array}$ & & & & & & 1000.10 & 79.94 & 59.58 & 59.50 & 9.27 & 9.34 & 1.152 \\
\hline $\begin{array}{l}\text { C80-10- } \\
1 \mathrm{H} 3-1\end{array}$ & & & & & & 1000.0 & 78.55 & 58.48 & 59.23 & 10.15 & 10.04 & 0.753 \\
\hline $\begin{array}{l}\text { C80-10- } \\
2 \mathrm{H} 3-2\end{array}$ & & & & & & 999.8 & 79.04 & 60.39 & 59.88 & 9.79 & 9.05 & 0.584 \\
\hline $\begin{array}{l}\text { C80-10- } \\
2 \mathrm{H} 5-1\end{array}$ & & & & & & 1000.1 & 79.19 & 59.03 & 58.92 & 10.03 & 10.39 & 0.754 \\
\hline $\begin{array}{l}\text { C80-10- } \\
2 \mathrm{H} 5-2\end{array}$ & & & & & & 999.8 & 78.63 & 59.53 & 60.14 & 16.66 & 9.78 & 0.642 \\
\hline $\begin{array}{l}\text { C80-10- } \\
2 \mathrm{H} 7-1\end{array}$ & & & & & & 999.9 & 79.46 & 59.55 & 59.49 & 10.06 & 9.85 & 1.068 \\
\hline $\begin{array}{l}\text { C80-10- } \\
2 \mathrm{H} 7-2\end{array}$ & & & & & & 999.8 & 79.14 & 59.14 & 59.63 & 9.75 & 9.74 & 1.102 \\
\hline
\end{tabular}


TABle 1: Continued.

\begin{tabular}{|c|c|c|c|c|c|c|c|c|c|c|c|c|}
\hline \multirow[b]{2}{*}{ Specimen } & \multicolumn{5}{|c|}{ Nominal dimensions } & \multicolumn{6}{|c|}{ Measured dimensions } & \multirow[b]{2}{*}{$\begin{array}{c}\text { Maximal initial } \\
\text { imperfection } \Delta_{\max }(\mathrm{mm})\end{array}$} \\
\hline & $\begin{array}{c}L \\
(\mathrm{~mm})\end{array}$ & $\begin{array}{c}h \\
(\mathrm{~mm})\end{array}$ & $\begin{array}{c}b \\
(\mathrm{~mm})\end{array}$ & $\begin{array}{c}a \\
(\mathrm{~mm})\end{array}$ & $\begin{array}{c}t \\
(\mathrm{~mm})\end{array}$ & $\begin{array}{c}L_{1} \\
(\mathrm{~mm})\end{array}$ & $\begin{array}{c}h_{1} \\
(\mathrm{~mm})\end{array}$ & $\begin{array}{c}b_{1} \\
(\mathrm{~mm})\end{array}$ & $\begin{array}{c}b_{2} \\
(\mathrm{~mm})\end{array}$ & $\begin{array}{c}a_{1} \\
(\mathrm{~mm})\end{array}$ & $\begin{array}{c}a_{2} \\
(\mathrm{~mm})\end{array}$ & \\
\hline $\begin{array}{l}\mathrm{C} 80-20- \\
\mathrm{NH}-1\end{array}$ & & & & & & 2000.16 & 79.22 & 58.12 & 58.46 & 9.69 & 9.96 & 1.015 \\
\hline $\begin{array}{l}\mathrm{C} 80-20- \\
\mathrm{NH}-2\end{array}$ & & & & & & 1999.94 & 79.09 & 59.13 & 59.47 & 9.48 & 9.68 & 1.007 \\
\hline $\begin{array}{l}\text { C80-20- } \\
3 \mathrm{H} 3-1\end{array}$ & & & & & & 1999.66 & 79.08 & 58.73 & 59.68 & 8.75 & 9.23 & 0.796 \\
\hline $\begin{array}{l}\text { C80-20- } \\
3 \mathrm{H} 3-2\end{array}$ & & & & & & 1999.72 & 78.37 & 59.67 & 59.25 & 9.48 & 8.57 & 0.874 \\
\hline $\begin{array}{l}\text { C80-20- } \\
3 \mathrm{H} 5-1\end{array}$ & 2000 & 80 & 60 & 10 & 0.8 & 2000.13 & 79.44 & 58.21 & 58.82 & 9.87 & 9.41 & 1.122 \\
\hline $\begin{array}{l}\text { C80-20- } \\
3 \mathrm{H} 5-2\end{array}$ & & & & & & 1999.83 & 78.89 & 58.45 & 58.87 & 9.78 & 9.49 & 0.923 \\
\hline $\begin{array}{l}\text { C80-20- } \\
3 \mathrm{H} 7-1\end{array}$ & & & & & & 2000.09 & 79.13 & 57.86 & 58.69 & 9.64 & 9.91 & 0.905 \\
\hline $\begin{array}{l}\text { C80-20- } \\
3 \mathrm{H} 7-2\end{array}$ & & & & & & 2000.17 & 79.67 & 57.82 & 58.45 & 9.99 & 9.80 & 1.053 \\
\hline $\begin{array}{l}\text { C90-05- } \\
\mathrm{NH}-1\end{array}$ & & & & & & 499.53 & 87.05 & 49.29 & 48.69 & 14.85 & 15.27 & 0.917 \\
\hline $\begin{array}{l}\text { C90-05- } \\
\mathrm{NH}-2\end{array}$ & & & & & & 499.45 & 87.75 & 49.08 & 48.85 & 14.67 & 14.84 & 0.916 \\
\hline $\begin{array}{l}\text { C90-05- } \\
1 \mathrm{H} 3-1\end{array}$ & & & & & & 499.66 & 89.04 & 48.78 & 48.75 & 14.57 & 14.87 & 0.757 \\
\hline $\begin{array}{l}\text { C90-05- } \\
1 \mathrm{H} 3-2\end{array}$ & & & & & & 499.73 & 87.36 & 48.93 & 48.99 & 14.75 & 14.99 & 0.466 \\
\hline $\begin{array}{l}\text { C90-05- } \\
1 \mathrm{H} 5-1\end{array}$ & 500 & 90 & 50 & 15 & 0.8 & 499.57 & 86.79 & 49.02 & 49.36 & 14.88 & 15.52 & 0.589 \\
\hline $\begin{array}{l}\text { C90-05- } \\
\text { 1H5-2 }\end{array}$ & & & & & & 499.68 & 89.89 & 48.72 & 48.57 & 14.80 & 15.23 & 0.872 \\
\hline $\begin{array}{l}\text { C90-05- } \\
1 \mathrm{H} 7-1\end{array}$ & & & & & & 499.66 & 87.31 & 49.03 & 48.92 & 14.77 & 15.18 & 0.866 \\
\hline $\begin{array}{l}\text { C90-05- } \\
1 \mathrm{H} 7-2\end{array}$ & & & & & & 499.69 & 86.76 & 48.95 & 48.76 & 14.69 & 14.87 & 0.874 \\
\hline $\begin{array}{l}\text { C90-10- } \\
\text { NH-1 }\end{array}$ & & & & & & 1000.3 & 89.33 & 50.03 & 49.73 & 14.39 & 13.95 & 1.101 \\
\hline $\begin{array}{l}\text { C90-10- } \\
\mathrm{NH}-2\end{array}$ & & & & & & 1000.22 & 89.24 & 48.93 & 49.65 & 14.62 & 15.13 & 1.107 \\
\hline $\begin{array}{l}\text { C90-10- } \\
1 \mathrm{H} 3-1\end{array}$ & & & & & & 999.9 & 89.44 & 49.03 & 49.54 & 14.18 & 14.67 & 1.067 \\
\hline $\begin{array}{l}\text { C90-10- } \\
1 \mathrm{H} 3-2\end{array}$ & & & & & 0.8 & 999.9 & 89.82 & 48.87 & 49.41 & 14.34 & 14.84 & 1.181 \\
\hline $\begin{array}{l}\text { C90-10- } \\
\text { 1H5-1 }\end{array}$ & 1000 & 90 & 50 & 15 & 0.8 & 999.9 & 88.52 & 49.97 & 48.92 & 14.95 & 14.58 & 1.205 \\
\hline $\begin{array}{l}\text { C90-10- } \\
1 \mathrm{H} 5-2\end{array}$ & & & & & & 1000.0 & 89.14 & 48.76 & 49.18 & 14.87 & 15.01 & 1.201 \\
\hline $\begin{array}{l}\text { C90-10- } \\
1 \mathrm{H} 7-1\end{array}$ & & & & & & 999.91 & 89.42 & 49.73 & 49.19 & 14.96 & 13.93 & 1.166 \\
\hline $\begin{array}{l}\text { C90-10- } \\
1 \mathrm{H} 7-2\end{array}$ & & & & & & 1000.0 & 89.35 & 49.56 & 49.53 & 14.17 & 14.88 & 1.109 \\
\hline
\end{tabular}


Table 1: Continued.

\begin{tabular}{|c|c|c|c|c|c|c|c|c|c|c|c|c|}
\hline \multirow[b]{2}{*}{ Specimen } & \multicolumn{5}{|c|}{ Nominal dimensions } & \multicolumn{6}{|c|}{ Measured dimensions } & \multirow[b]{2}{*}{$\begin{array}{l}\text { Maximal initial } \\
\text { imperfection } \Delta_{\max }(\mathrm{mm})\end{array}$} \\
\hline & $\begin{array}{c}L \\
(\mathrm{~mm})\end{array}$ & $\begin{array}{c}h \\
(\mathrm{~mm})\end{array}$ & $\begin{array}{c}b \\
(\mathrm{~mm})\end{array}$ & $\begin{array}{c}a \\
(\mathrm{~mm})\end{array}$ & $\begin{array}{c}t \\
(\mathrm{~mm})\end{array}$ & $\begin{array}{c}L_{1} \\
(\mathrm{~mm})\end{array}$ & $\begin{array}{c}h_{1} \\
(\mathrm{~mm})\end{array}$ & $\begin{array}{c}b_{1} \\
(\mathrm{~mm})\end{array}$ & $\begin{array}{c}b_{2} \\
(\mathrm{~mm})\end{array}$ & $\begin{array}{c}a_{1} \\
(\mathrm{~mm})\end{array}$ & $\begin{array}{c}a_{2} \\
(\mathrm{~mm})\end{array}$ & \\
\hline $\begin{array}{l}\text { C90-20- } \\
\text { NH-1 }\end{array}$ & & & & & & 1999.82 & 87.26 & 48.94 & 49.18 & 14.61 & 15.12 & 1.063 \\
\hline $\begin{array}{l}\mathrm{C} 90-20- \\
\mathrm{NH}-2\end{array}$ & & & & & & 1999.45 & 87.21 & 49.27 & 49.54 & 14.67 & 14.99 & 1.106 \\
\hline $\begin{array}{l}\text { C90-20- } \\
3 \mathrm{H} 3-1\end{array}$ & & & & & & 1999.76 & 87.13 & 48.22 & 49.63 & 14.02 & 14.59 & 0.936 \\
\hline $\begin{array}{l}\text { C90-20- } \\
3 \mathrm{H} 3-2\end{array}$ & & & & & & 1999.89 & 87.15 & 47.45 & 48.78 & 15.25 & 14.78 & 0.947 \\
\hline $\begin{array}{l}\text { C90-20- } \\
3 \mathrm{H} 5-1\end{array}$ & 2000 & 90 & 50 & 15 & 0.8 & 1999.55 & 85.60 & 48.91 & 50.31 & 13.88 & 14.86 & 0.985 \\
\hline $\begin{array}{l}\text { C90-20- } \\
3 \mathrm{H} 5-2\end{array}$ & & & & & & 2000.18 & 87.27 & 49.51 & 49.02 & 14.29 & 14.65 & 0.974 \\
\hline $\begin{array}{l}\text { C90-20- } \\
3 \mathrm{H} 7-1\end{array}$ & & & & & & 1999.07 & 87.29 & 49.51 & 49.14 & 14.69 & 14.88 & 1.015 \\
\hline $\begin{array}{l}\text { C90-20- } \\
3 \mathrm{H} 7-2\end{array}$ & & & & & & 1999.26 & 87.27 & 49.51 & 49.25 & 14.41 & 14.81 & 0.967 \\
\hline
\end{tabular}

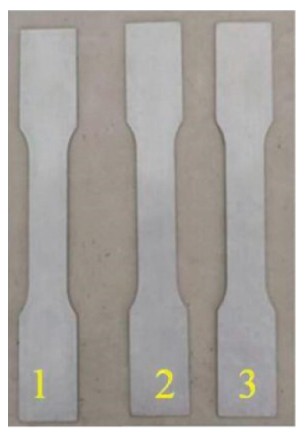

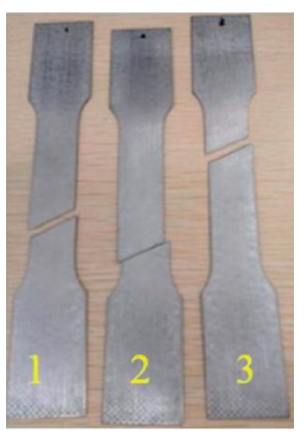

(a)
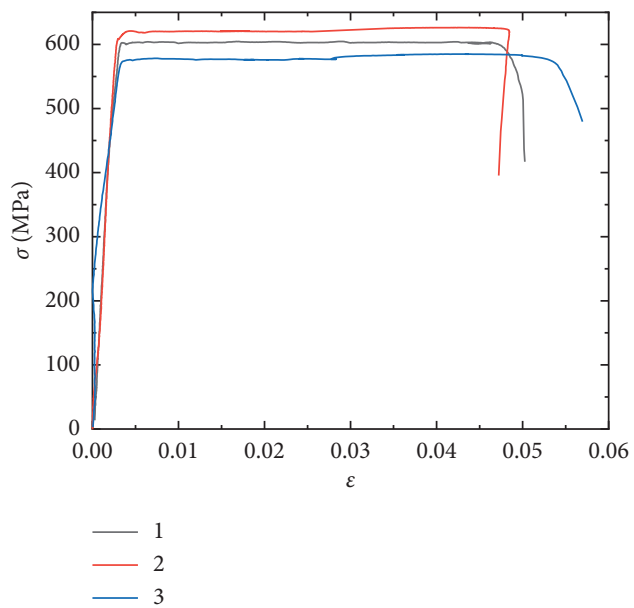

(b)

Figure 4: Coupon tests. (a) Tension coupons and failure modes of coupons. (b) Stress-strain curves of tension coupons.

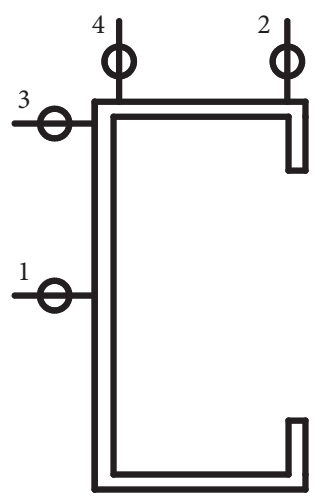

FIgURE 5: Measured locations for initial geometric imperfections. 


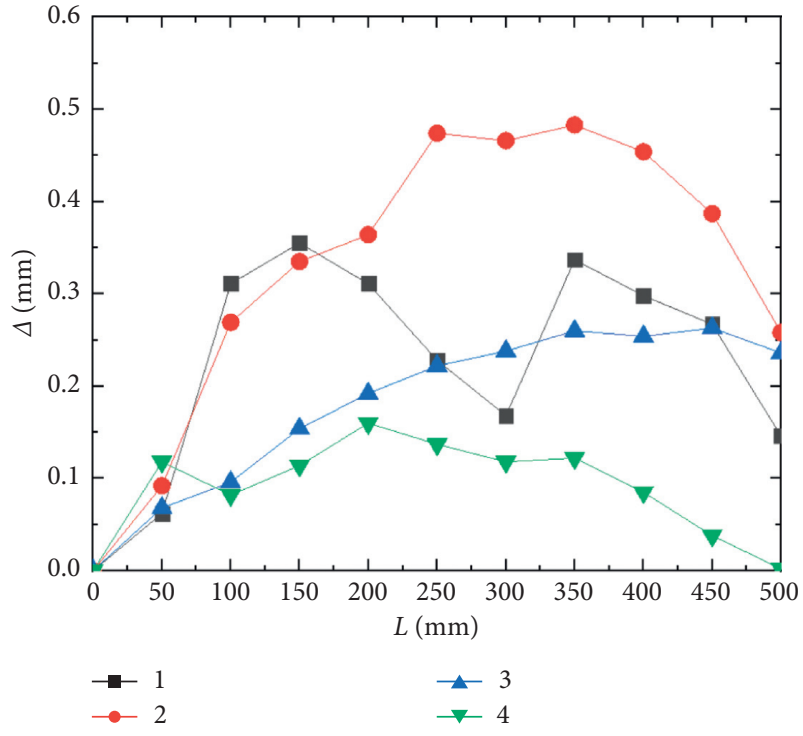

(a)

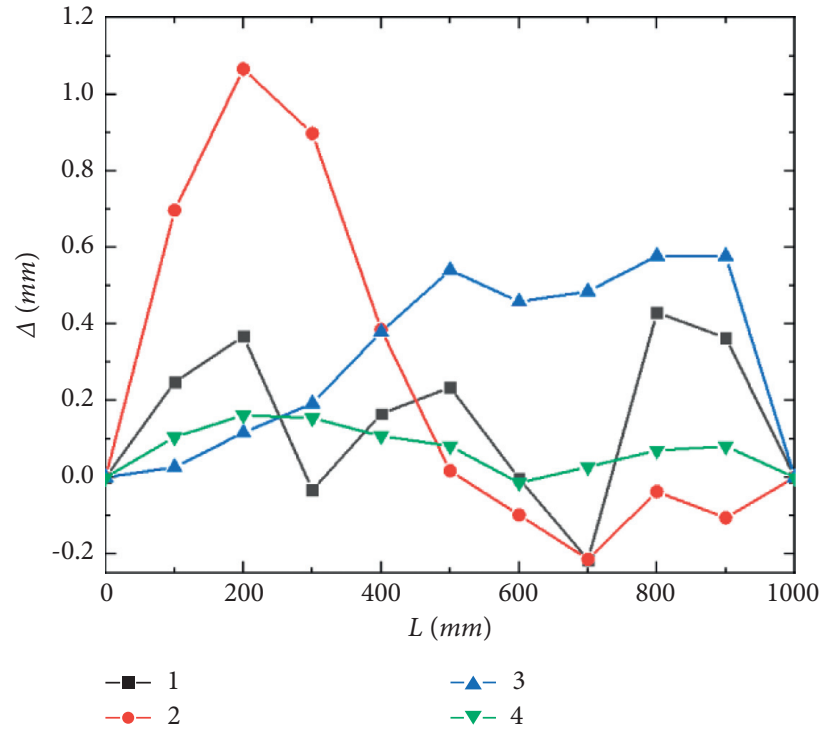

(b)

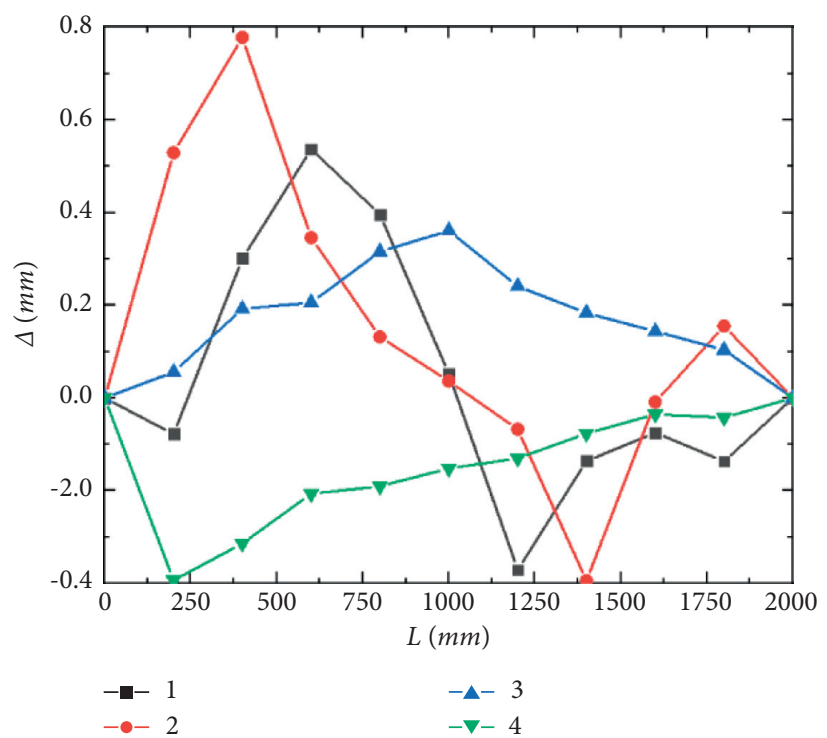

(c)

Figure 6: Initial geometric imperfections of specimens. (a)Specimen C80-05-1H3-1. (b)Specimen C80-10-1H3-1. (c)Specimen C80-20$3 \mathrm{H} 3-1$.

and 10(b)) with the increase in the load. Finally, the specimens failed with the interaction of local buckling and distortional buckling (Figures 9(d) and 10(c)).

For column specimens with the length of $2000 \mathrm{~mm}$, the local buckling was found firstly (Figure 11(a)). Then, the specimens displayed the distortional buckling with the gradual increase in the load (Figure 11(b)). Finally, the specimens failed with interaction of local buckling, distortional buckling, and overall buckling (flexural buckling or flexural-torsional buckling, as shown in Figures 11(c) and $11(d)$ ).

All specimens with the ratios of the diameter of the circular hole to the height of the web equaling to 0.5 and 0.7 displayed the plastic local buckling failure in the plate adjacent to the circular hole, as shown in Figure 12.
3.2. Load versus Strain Curves. The load versus strain curves of the plates adjacent to circular holes (strain gauge 4) and the plates at cross section without circular holes (strain gauge 1) for section C90-10 with different circular hole sizes are shown in Figure 13. It can be observed from Figure 13(a) that the axial strains gradually increase as the diameters of circular holes increase because of the stress concentration of the plates adjacent to circular holes. However, the strains at cross section without circular hole as shown in Figure 13(b) are almost the same for specimens with different hole diameters, which indicates that the circular hole has no effect on strain for the plate away from the circular hole.

The load-strain curves of the specimen C80-10-1H3-1 and the specimen C80-10-1H7-1 at cross sections without holes and with circular holes are shown in Figure 14. For 

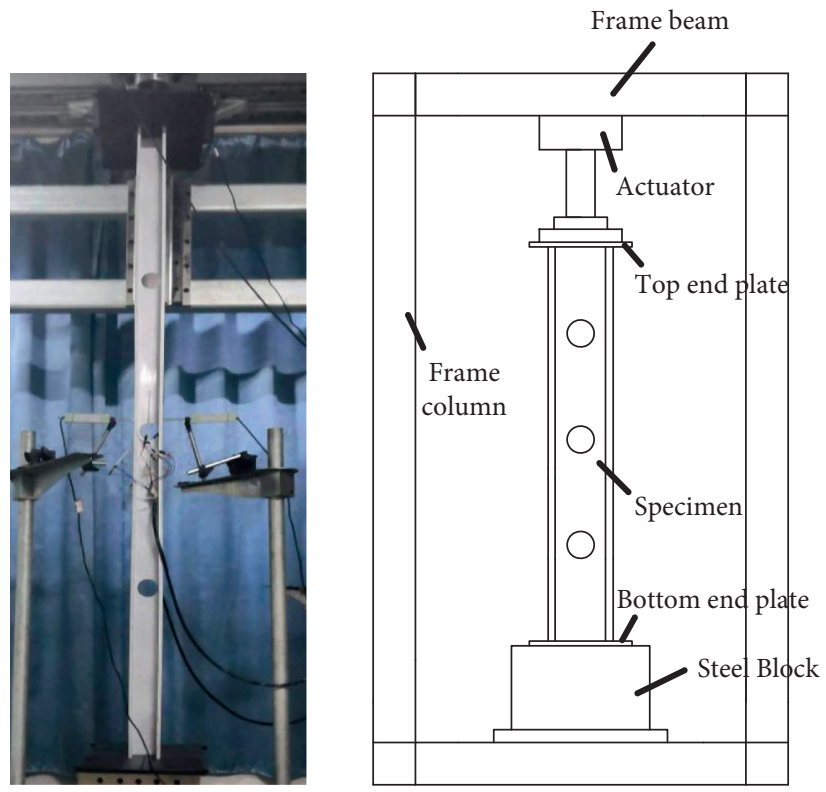

Figure 7: Test rig.

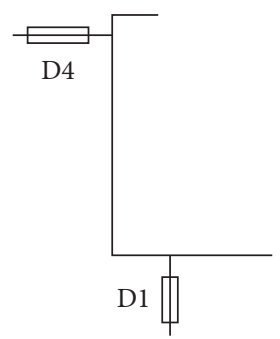

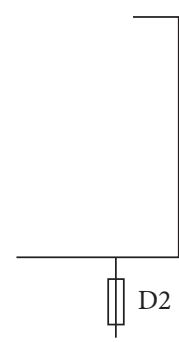

(a)

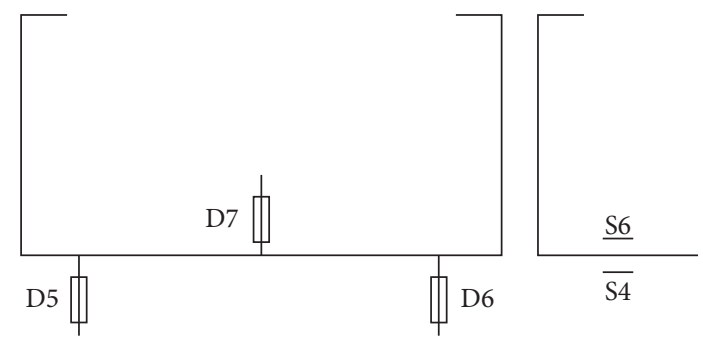

(b)

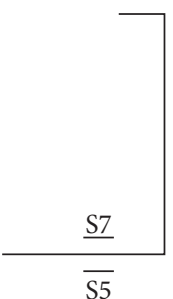

(c)

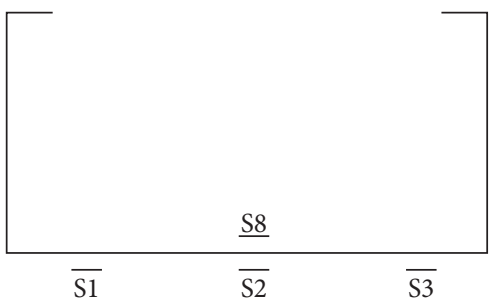

(d)

Figure 8: Instrumentation arrangement. LVDTs for specimens (a) with holes and (b) without holes. Strain gauges for specimens (c) with holes and (d) without holes.

the specimen $\mathrm{C} 80-10-1 \mathrm{H} 3-1$, the buckling loads in the web were $13.9 \mathrm{kN}$ and $14.2 \mathrm{kN}$ at cross section without circular holes and cross section with circular holes, as shown in Figures $14(\mathrm{a})$ and $14(\mathrm{~b})$, respectively. The comparison indicates that the presence of small circular holes has slight effect on the local buckling load of the web. However, for the specimen C80-10-1H7-1, Figures 14(c) and $14(\mathrm{~d})$ show that the local buckling loads are $11.8 \mathrm{kN}$ and $18.2 \mathrm{kN}$ for the web at cross section without holes and cross section with circular holes, which means the large circular hole has great effect on the local buckling load of the web.
3.3. Failure Loads and Load versus Shorten Displacement Response. The failure loads $\left(P_{\mathrm{t}}\right)$ of all specimens are summarized in Table 2. It can be observed from Table 2 that the failure loads for sections C80 and C90 with the length of $500 \mathrm{~mm}$ and circular hole size $(d / h)$ of $0.3,0.5$, and 0.7 reduce maximum by $0.93 \%, 6.05 \%, 11.59 \%$ and $4.1 \%, 7.12 \%, 16.58 \%$ compared with the same sections without circular holes, respectively. The failure loads for sections C80 and C90 with the length of $1000 \mathrm{~mm}$ and hole size $(d / h)$ of $0.3,0.5$, and 0.7 decrease maximum by $3.57 \%, 8.12 \%, 13.21 \%$ and $2.54 \%$, $5.71 \%, 15.77 \%$ corresponding to the same sections without circular holes, respectively. The failure loads reduce by $6.68 \%$, 
$12 \%, 18.29 \%$ and $7.43 \%, 15.01 \%, 20.5 \%$ compared the specimens without circular holes for sections C80 and C90 with the length of $2000 \mathrm{~mm}$ and hole size $(d / h)$ of $0.3,0.5$, and 0.7 , respectively. The comparisons on decrease rate of the failure loads indicate that the failure loads of the specimens decreases obviously as the diameter of the circular holes increase. Meanwhile, for section C80-10, it can be observed that the failure load of specimens with two circular holes is less than that of the same section with one circular hole.

The comparison on load-axial shorten displacement curves of section C90-20 with different diameters of circular holes is shown in Figure 15. Figure 15 shows that the failure loads and stiffness of the specimens with the same section decrease with increase in the diameters of circular holes.

\section{Numerical Simulations}

4.1. Development and Validation of Finite Element Models. The finite element software program ABAQUS [22] was employed to simulate the buckling modes, obtain the failure loads of the test columns, and make a further parametric study on CFS lipped channel columns with circular holes. The FEM and analysis progress developed by authors can be found in reference [9]. The buckling modes and the failure loads $\left(P_{\mathrm{a}}\right)$ of all specimens obtained from $\mathrm{FE}$ analysis are summarized in Table 2. As shown in Table 2, the buckling modes obtained from the FE analysis are consistent with the test results for all specimens. The average ratio of test results to FE results $\left(P_{\mathrm{t}} / P_{\mathrm{A}}\right)$ is 0.9933 with the corresponding coefficient of variation of 0.0271 . Meanwhile, the maximum deviations of failure loads between FE results and the tests are less than $8 \%$. The comparisons on failure modes between FE analysis and the tests depicted in Figure 16 for the specimens C90-05-1H7-2, C90-10-1H5-2, C90-10-3H7-2, and $\mathrm{C} 90-20-1 \mathrm{H} 7-2$ show a great agreement. The load-axial shorten displacement curves of the specimens C80-10-2H32, C80-10-2H5-2, and C80-10-2H7-2 obtained from the FE analysis match well with the test result, as plotted in Figure 17. With the basics of the abovementioned comparisons, the FEM developed by authors to simulate CFS axial compression members with circular holes has been well validated and can be used to further analyze failure loads of CFS lipped channel columns with circular holes.

4.2. FE Parametric Studies for Analyzing the Numerical Failure Loads. The validated FEM was used to further analyze the failure loads of CFS lipped channel columns with different circular hole sizes and lengths under axial compression. The section dimensions and the failure loads obtained from the FE analysis for CFS lipped channel columns with circular holes are shown in Table 3.

As shown in Table 3, the failure loads of CFS lipped channel columns with circular holes decrease gradually with the increase in the diameters of circular holes. For example, for the section $\mathrm{C} 89 \times 41 \times 13 \times 1$ with the length of $1000 \mathrm{~mm}$, the hole size $(d / h)$ of 0.5 and 0.7 causes a decrease in the failure loads to $6.1 \%$ and $17.26 \%$ for the same section without circular holes, respectively.

\subsection{Proposed Distortional Buckling Coefficient of Axial Compression Members with Circular Holes}

4.3.1. Effect on Distortional Buckling Coefficient of Single Circular Hole. The lipped channel section $(h=110 \mathrm{~mm}$, $b=60 \mathrm{~mm}, a=12 \mathrm{~mm}$, and $t=1.5 \mathrm{~mm}$ ) with a circular hole was selected to analyze the distortional buckling stress and coefficient. The length of the axial compression column was assumed equal to $1200 \mathrm{~mm}$, which was the triple of the distortional buckling half wavelength. The ratios of diameter of circular hole to the height of web $(d / h)$ changed from 0 to 0.7. The variations of ratios of $k_{\mathrm{a}} / k_{0}$ are plotted against the ratio of $d / h$ in Figure 18 , where $k_{\mathrm{a}}$ and $k_{0}$ are defined as the distortional buckling coefficients of axial compression columns with a circular hole and without holes obtained from $\mathrm{FE}$ analysis, respectively. As shown in Figure 18, the distortional buckling coefficients of the CFS lipped channel column with a circular hole decrease with the increase in the ratios of $d / h$, which indicates that the diameter of circular hole has a great influence on the distortional buckling coefficient.

4.3.2. Effect of Multiple Circular Holes on Distortional Buckling Coefficient. The lipped channel columns with same section and length were used to analyze the distortional buckling coefficient of the axial compression column with multiple circular holes. Three circular holes with two different hole spacings (i.e. $S=150$ and $400 \mathrm{~mm}$ ) were equally set from the middle cross section of the column to ends. The $d / h$ changed also from 0.1 to 0.7 . The variation of ratios of $k_{\mathrm{a}} / k_{0}$ versus $d / h$ curves are depicted in Figure 19. Figure 19 indicates that same number of circular holes with different hole spacings has a slight effect on the distortional buckling coefficient. Hence, the distortional buckling coefficient may neglect the effect of hole spacings.

Figure 20 shows the distortional buckling coefficient of CFS lipped channel columns with three circular holes having different hole sizes ( $d / h$ ranging from 0.1 to 0.7 ) and five different hole spacings (i.e., $S=150,200,300$, 400 , and $500 \mathrm{~mm}$ ). This figure illustrates the laws of change of $k_{\mathrm{a}} / k_{0}$ with the change of the hole spacing are almost constant for the axial compression columns with different circular hole sizes. When the hole spacing is equal to $400 \mathrm{~mm}$ which is the half wavelength of distortional buckling of the analyzed column, $k_{\mathrm{a}} / k_{0}$ reaches the minimum. Thus, the distortional buckling coefficient of the CFS lipped channel section with multiple circular holes under axial compression can conservative employed the distortional buckling coefficient of the axial compression column when the holes spacing is equal to the distortional buckling half wavelength.

4.3.3. Proposed Calculation Method for the Distortional Buckling Coefficient. In order to consider the effect of the circular hole on the distortional buckling coefficient, the reduced distortional buckling coefficients of the CFS lipped channel column with a circular hole and multiple circular holes can be calculated by using the formulas $k_{1}=\mu_{1} k$ and $k_{2}=\mu_{2} k$, respectively, where $k$ is the distortional buckling 
TABLE 2: Comparison on failure modes and failure loads of specimens.

\begin{tabular}{|c|c|c|c|c|c|c|c|c|}
\hline Specimen & $\begin{array}{l}\text { Buckling mode in } \\
\text { test }\end{array}$ & $\begin{array}{l}\text { Buckling mode in FE } \\
\text { analysis }\end{array}$ & $\begin{array}{c}P_{\mathrm{t}} \\
(\mathrm{kN})\end{array}$ & $\begin{array}{l}\text { Rate of reduction of capacity } \\
(\%)\end{array}$ & $\begin{array}{c}P_{\mathrm{a}} \\
(\mathrm{kN})\end{array}$ & $\begin{array}{c}P_{\mathrm{c}} \\
(\mathrm{kN})\end{array}$ & $P_{\mathrm{t}} / P_{\mathrm{a}}$ & $P_{\mathrm{t}} / P_{\mathrm{c}}$ \\
\hline $\begin{array}{c}\mathrm{C} 80-05-\mathrm{NH}- \\
1\end{array}$ & $\mathrm{~L}+\mathrm{D}$ & $\mathrm{L}+\mathrm{D}$ & 34.04 & & 35.09 & 33.70 & 0.971 & 1.012 \\
\hline $\begin{array}{c}\mathrm{C} 80-05-\mathrm{NH}- \\
2\end{array}$ & $\mathrm{~L}+\mathrm{D}$ & $\mathrm{L}+\mathrm{D}$ & 35.61 & & 35.97 & 33.83 & 0.990 & 1.053 \\
\hline $\begin{array}{c}\text { C80-05-1H3- } \\
1\end{array}$ & $\mathrm{~L}+\mathrm{D}$ & $\mathrm{L}+\mathrm{D}$ & 34.57 & 0.71 & 37.41 & 33.41 & 0.924 & 1.035 \\
\hline $\begin{array}{c}\text { C80-05-1H3- } \\
2\end{array}$ & $\mathrm{~L}+\mathrm{D}$ & $\mathrm{L}+\mathrm{D}$ & 34.50 & 0.93 & 36.70 & 33.13 & 0.940 & 1.042 \\
\hline $\begin{array}{c}\text { C80-05-1H5- } \\
1\end{array}$ & $\mathrm{~L}+\mathrm{D}$ & $\mathrm{L}+\mathrm{D}$ & 32.72 & 6.05 & 34.16 & 32.27 & 0.958 & 1.014 \\
\hline $\begin{array}{c}\text { C80-05-1H5- } \\
2\end{array}$ & $\mathrm{~L}+\mathrm{D}$ & $\mathrm{L}+\mathrm{D}$ & 32.84 & 5.71 & 34.61 & 32.12 & 0.949 & 1.023 \\
\hline $\begin{array}{c}\text { C80-05-1H7- } \\
1\end{array}$ & $\mathrm{~L}+\mathrm{D}$ & $\mathrm{L}+\mathrm{D}$ & 31.04 & 10.86 & 31.35 & 30.41 & 0.991 & 1.021 \\
\hline $\begin{array}{c}\text { C80-05-1H7- } \\
2\end{array}$ & $\mathrm{~L}+\mathrm{D}$ & $\mathrm{L}+\mathrm{D}$ & 30.79 & 11.59 & 32.41 & 29.87 & 0.951 & 1.031 \\
\hline $\begin{array}{c}\text { C80-10-NH- } \\
1\end{array}$ & $\mathrm{~L}+\mathrm{D}$ & $\mathrm{L}+\mathrm{D}$ & 27.24 & & 28.02 & 26.22 & 0.972 & 1.039 \\
\hline $\begin{array}{c}\mathrm{C} 80-10-\mathrm{NH}- \\
2\end{array}$ & $\mathrm{~L}+\mathrm{D}$ & $\mathrm{L}+\mathrm{D}$ & 27.57 & & 28.02 & 26.88 & 0.984 & 1.026 \\
\hline $\begin{array}{c}\text { C80-10-1H3- } \\
1\end{array}$ & $\mathrm{~L}+\mathrm{D}$ & $\mathrm{L}+\mathrm{D}$ & 26.86 & 2.02 & 26.98 & 26.56 & 0.996 & 1.011 \\
\hline $\begin{array}{c}\text { C80-10-1H3- } \\
2\end{array}$ & $\mathrm{~L}+\mathrm{D}$ & $\mathrm{L}+\mathrm{D}$ & 26.43 & 3.57 & 27.40 & 25.76 & 0.965 & 1.026 \\
\hline $\begin{array}{c}\text { C80-10-1H5- } \\
1\end{array}$ & $\mathrm{~L}+\mathrm{D}$ & $\mathrm{L}+\mathrm{D}$ & 25.83 & 5.78 & 25.48 & 25.29 & 1.014 & 1.021 \\
\hline $\begin{array}{c}\text { C80-10-1H5- } \\
2\end{array}$ & $\mathrm{~L}+\mathrm{D}$ & $\mathrm{L}+\mathrm{D}$ & 25.19 & 8.12 & 25.61 & 24.78 & 0.983 & 1.016 \\
\hline $\begin{array}{c}\text { C80-10-1H7- } \\
1\end{array}$ & $\mathrm{~L}+\mathrm{D}$ & $\mathrm{L}+\mathrm{D}$ & 24.26 & 11.52 & 23.76 & 24.11 & 1.021 & 1.006 \\
\hline $\begin{array}{c}\text { C80-10-1H7- } \\
2\end{array}$ & $\mathrm{~L}+\mathrm{D}$ & $\mathrm{L}+\mathrm{D}$ & 23.78 & 13.21 & 24.53 & 23.87 & 0.969 & 0.996 \\
\hline $\begin{array}{c}\text { C80-10-2H3- } \\
1\end{array}$ & $\mathrm{~L}+\mathrm{D}$ & $\mathrm{L}+\mathrm{D}$ & 26.48 & 3.40 & 26.41 & 25.86 & 1.003 & 1.024 \\
\hline $\begin{array}{c}\mathrm{C} 80-10-2 \mathrm{H} 3- \\
2\end{array}$ & $\mathrm{~L}+\mathrm{D}$ & $\mathrm{L}+\mathrm{D}$ & 26.40 & 3.69 & 25.93 & 25.72 & 1.018 & 1.027 \\
\hline $\begin{array}{c}\text { C80-10-2H5- } \\
1\end{array}$ & $\mathrm{~L}+\mathrm{D}$ & $\mathrm{L}+\mathrm{D}$ & 24.55 & 10.41 & 25.29 & 24.96 & 0.971 & 0.984 \\
\hline $\begin{array}{c}\text { C } 80-10-2 H 5- \\
2\end{array}$ & $\mathrm{~L}+\mathrm{D}$ & $\mathrm{L}+\mathrm{D}$ & 24.50 & 10.62 & 23.98 & 24.30 & 1.022 & 1.008 \\
\hline $\begin{array}{c}\text { C80-10-2H7- } \\
1\end{array}$ & $\mathrm{~L}+\mathrm{D}$ & $\mathrm{L}+\mathrm{D}$ & 23.86 & 12.96 & 23.73 & 23.54 & 1.005 & 1.013 \\
\hline $\begin{array}{c}\text { C80-10-2H7- } \\
2 \\
\end{array}$ & $\mathrm{~L}+\mathrm{D}$ & $\mathrm{L}+\mathrm{D}$ & 23.56 & 14.05 & 23.67 & 22.79 & 0.995 & 1.034 \\
\hline $\begin{array}{c}\mathrm{C} 80-20-\mathrm{NH}- \\
1\end{array}$ & $\mathrm{~L}+\mathrm{D}+\mathrm{FT}$ & $\mathrm{L}+\mathrm{D}+\mathrm{FT}$ & 20.17 & & 19.53 & 20.62 & 1.032 & 0.978 \\
\hline $\begin{array}{c}\mathrm{C} 80-20-\mathrm{NH}- \\
2\end{array}$ & $\mathrm{~L}+\mathrm{D}+\mathrm{FT}$ & $\mathrm{L}+\mathrm{D}+\mathrm{FT}$ & 20.78 & & 20.42 & 20.32 & 1.017 & 1.022 \\
\hline $\begin{array}{c}\mathrm{C} 80-20-3 \mathrm{H} 3- \\
1\end{array}$ & $\mathrm{~L}+\mathrm{D}+\mathrm{FT}$ & $\mathrm{L}+\mathrm{D}+\mathrm{FT}$ & 19.11 & 6.68 & 18.40 & 19.05 & 1.038 & 1.003 \\
\hline $\begin{array}{c}\mathrm{C} 80-20-3 \mathrm{H} 3- \\
2\end{array}$ & $\mathrm{~L}+\mathrm{D}+\mathrm{FT}$ & $\mathrm{L}+\mathrm{D}+\mathrm{FT}$ & 19.26 & 5.96 & 18.19 & 19.49 & 1.059 & 0.988 \\
\hline $\begin{array}{c}\text { C80-20-3H5- } \\
1\end{array}$ & $\mathrm{~L}+\mathrm{D}+\mathrm{FT}$ & $\mathrm{L}+\mathrm{D}+\mathrm{FT}$ & 18.20 & 11.13 & 17.16 & 18.97 & 1.061 & 0.959 \\
\hline $\begin{array}{c}\text { C80-20-3H5- } \\
2\end{array}$ & $\mathrm{~L}+\mathrm{D}+\mathrm{FT}$ & $\mathrm{L}+\mathrm{D}+\mathrm{FT}$ & 18.02 & 12.00 & 17.33 & 19.00 & 1.039 & 0.948 \\
\hline $\begin{array}{c}\text { C80-20-3H7- } \\
1\end{array}$ & $\mathrm{~L}+\mathrm{D}+\mathrm{F}$ & $\mathrm{L}+\mathrm{D}+\mathrm{F}$ & 17.10 & 16.50 & 16.86 & 17.33 & 1.014 & 0.987 \\
\hline $\begin{array}{c}\text { C80-20-3H7- } \\
2\end{array}$ & $\mathrm{~L}+\mathrm{D}+\mathrm{F}$ & $\mathrm{L}+\mathrm{D}+\mathrm{F}$ & 16.73 & 18.29 & 17.04 & 17.33 & 0.982 & 0.965 \\
\hline
\end{tabular}


TABle 2: Continued.

\begin{tabular}{|c|c|c|c|c|c|c|c|c|}
\hline Specimen & $\begin{array}{c}\text { Buckling mode in } \\
\text { test }\end{array}$ & $\begin{array}{l}\text { Buckling mode in FE } \\
\text { analysis }\end{array}$ & $\begin{array}{c}P_{\mathrm{t}} \\
(\mathrm{kN})\end{array}$ & $\begin{array}{l}\text { Rate of reduction of capacity } \\
(\%)\end{array}$ & $\begin{array}{c}P_{\mathrm{a}} \\
(\mathrm{kN})\end{array}$ & $\begin{array}{c}P_{\mathrm{c}} \\
(\mathrm{kN})\end{array}$ & $P_{\mathrm{t}} / P_{\mathrm{a}}$ & $P_{\mathrm{t}} / P_{\mathrm{c}}$ \\
\hline $\begin{array}{c}\mathrm{C} 90-05-\mathrm{NH}- \\
1\end{array}$ & $\mathrm{~L}+\mathrm{D}$ & $\mathrm{L}+\mathrm{D}$ & 40.72 & & 41.55 & 39.09 & 0.980 & 1.042 \\
\hline $\begin{array}{c}\mathrm{C} 90-05-\mathrm{NH}- \\
2\end{array}$ & $\mathrm{~L}+\mathrm{D}$ & $\mathrm{L}+\mathrm{D}$ & 41.80 & & 43.09 & 38.87 & 0.970 & 1.075 \\
\hline $\begin{array}{c}\text { C90-05-1H3- } \\
1\end{array}$ & $\mathrm{~L}+\mathrm{D}$ & $\mathrm{L}+\mathrm{D}$ & 39.57 & 4.10 & 40.80 & 38.78 & 0.970 & 1.020 \\
\hline $\begin{array}{c}\text { C90-05-1H3- } \\
2\end{array}$ & $\mathrm{~L}+\mathrm{D}$ & $\mathrm{L}+\mathrm{D}$ & 39.83 & 3.48 & 40.64 & 38.63 & 0.980 & 1.031 \\
\hline $\begin{array}{c}\text { C90-05-1H5- } \\
1\end{array}$ & $\mathrm{~L}+\mathrm{D}$ & $\mathrm{L}+\mathrm{D}$ & 38.46 & 6.77 & 39.65 & 38.08 & 0.972 & 1.010 \\
\hline $\begin{array}{c}\text { C90-05-1H5- } \\
2\end{array}$ & $\mathrm{~L}+\mathrm{D}$ & $\mathrm{L}+\mathrm{D}$ & 38.32 & 7.12 & 40.71 & 38.28 & 0.941 & 1.001 \\
\hline $\begin{array}{c}\text { C90-05-1H7- } \\
1\end{array}$ & $\mathrm{~L}+\mathrm{D}$ & $\mathrm{L}+\mathrm{D}$ & 34.42 & 16.58 & 35.45 & 32.12 & 0.971 & 1.072 \\
\hline $\begin{array}{c}\text { C90-05-1H7- } \\
2 \\
\end{array}$ & $\mathrm{~L}+\mathrm{D}$ & $\mathrm{L}+\mathrm{D}$ & 35.14 & 14.85 & 37.50 & 34.05 & 0.937 & 1.032 \\
\hline $\begin{array}{c}\text { C90-10-NH- } \\
1\end{array}$ & $\mathrm{~L}+\mathrm{D}$ & $\mathrm{L}+\mathrm{D}$ & 38.51 & & 38.12 & 37.78 & 1.011 & 1.019 \\
\hline $\begin{array}{c}\mathrm{C} 90-10-\mathrm{NH}- \\
2\end{array}$ & $\mathrm{~L}+\mathrm{D}$ & $\mathrm{L}+\mathrm{D}$ & 38.31 & & 37.73 & 36.50 & 1.015 & 1.051 \\
\hline $\begin{array}{c}\text { C90-10-1H3- } \\
1\end{array}$ & $\mathrm{~L}+\mathrm{D}$ & $\mathrm{L}+\mathrm{D}$ & 37.44 & 2.54 & 36.99 & 35.67 & 1.012 & 1.052 \\
\hline $\begin{array}{c}\text { C90-10-1H3- } \\
2\end{array}$ & $\mathrm{~L}+\mathrm{D}$ & $\mathrm{L}+\mathrm{D}$ & 37.73 & 1.79 & 37.08 & 35.89 & 1.018 & 1.051 \\
\hline $\begin{array}{c}\text { C90-10-1H5- } \\
1\end{array}$ & $\mathrm{~L}+\mathrm{D}$ & $\mathrm{L}+\mathrm{D}$ & 36.22 & 5.71 & 35.58 & 35.79 & 1.018 & 1.012 \\
\hline $\begin{array}{c}\text { C90-10-1H5- } \\
2\end{array}$ & $\mathrm{~L}+\mathrm{D}$ & $\mathrm{L}+\mathrm{D}$ & 36.51 & 4.96 & 35.86 & 34.67 & 1.018 & 1.053 \\
\hline $\begin{array}{c}\text { C90-10-1H7- } \\
1\end{array}$ & $\mathrm{~L}+\mathrm{D}$ & $\mathrm{L}+\mathrm{D}$ & 32.36 & 15.77 & 33.46 & 31.59 & 0.967 & 1.024 \\
\hline $\begin{array}{c}\text { C90-10-1H7- } \\
2 \\
\end{array}$ & $\mathrm{~L}+\mathrm{D}$ & $\mathrm{L}+\mathrm{D}$ & 34.04 & 11.40 & 33.44 & 33.69 & 1.018 & 1.011 \\
\hline $\begin{array}{c}\mathrm{C} 90-20-\mathrm{NH}- \\
1\end{array}$ & $\mathrm{~L}+\mathrm{D}+\mathrm{FT}$ & $\mathrm{L}+\mathrm{D}+\mathrm{FT}$ & 23.48 & & 23.70 & 23.08 & 0.991 & 1.018 \\
\hline $\begin{array}{c}\text { C90-20-NH- } \\
2\end{array}$ & $\mathrm{~L}+\mathrm{D}+\mathrm{FT}$ & $\mathrm{L}+\mathrm{D}+\mathrm{FT}$ & 24.27 & & 23.68 & 23.28 & 1.025 & 1.043 \\
\hline $\begin{array}{c}\mathrm{C} 90-20-3 \mathrm{H} 3- \\
1\end{array}$ & $\mathrm{~L}+\mathrm{D}+\mathrm{FT}$ & $\mathrm{L}+\mathrm{D}+\mathrm{FT}$ & 22.11 & 7.43 & 21.38 & 21.84 & 1.034 & 1.012 \\
\hline $\begin{array}{c}\text { C90-20-3H3- } \\
2\end{array}$ & $\mathrm{~L}+\mathrm{D}+\mathrm{FT}$ & $\mathrm{L}+\mathrm{D}+\mathrm{FT}$ & 22.44 & 6.02 & 21.87 & 22.27 & 1.026 & 1.008 \\
\hline $\begin{array}{c}\text { C90-20-3H5- } \\
1\end{array}$ & $\mathrm{~L}+\mathrm{D}+\mathrm{FT}$ & $\mathrm{L}+\mathrm{D}+\mathrm{FT}$ & 21.25 & 11.05 & 20.81 & 21.17 & 1.021 & 1.004 \\
\hline $\begin{array}{c}\text { C90-20-3H5- } \\
2\end{array}$ & $\mathrm{~L}+\mathrm{D}+\mathrm{FT}$ & $\mathrm{L}+\mathrm{D}+\mathrm{FT}$ & 20.30 & 15.01 & 21.07 & 21.24 & 0.963 & 0.956 \\
\hline $\begin{array}{c}\text { C90-20-3H7- } \\
1\end{array}$ & $\mathrm{~L}+\mathrm{D}+\mathrm{F}$ & $\mathrm{L}+\mathrm{D}+\mathrm{F}$ & 18.99 & 20.50 & 19.38 & 18.90 & 0.981 & 1.005 \\
\hline $\begin{array}{c}\text { C90-20-3H7- } \\
2 \\
\end{array}$ & $\mathrm{~L}+\mathrm{D}+\mathrm{FT}$ & $\mathrm{L}+\mathrm{D}+\mathrm{FT}$ & 19.22 & 19.54 & 19.83 & 18.87 & 0.969 & 1.018 \\
\hline \multicolumn{7}{|c|}{ Average } & 0.9933 & 1.0172 \\
\hline & & Standard d & ation & & & & 0.0269 & 0.0194 \\
\hline \multicolumn{7}{|c|}{ Coefficient of variation } & 0.0271 & 0.0190 \\
\hline
\end{tabular}




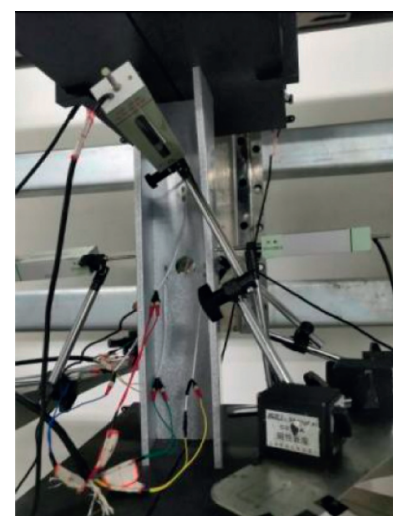

(a)

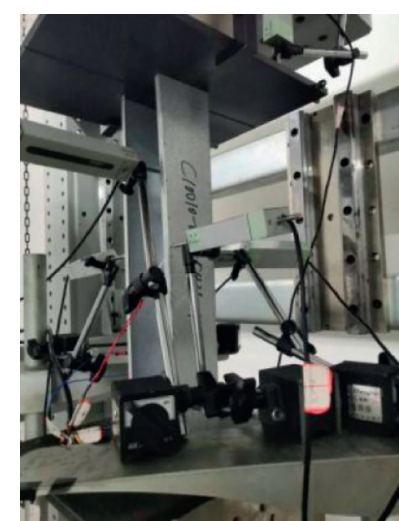

(b)

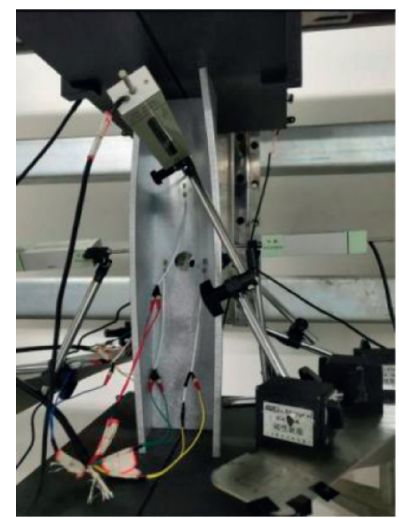

(c)

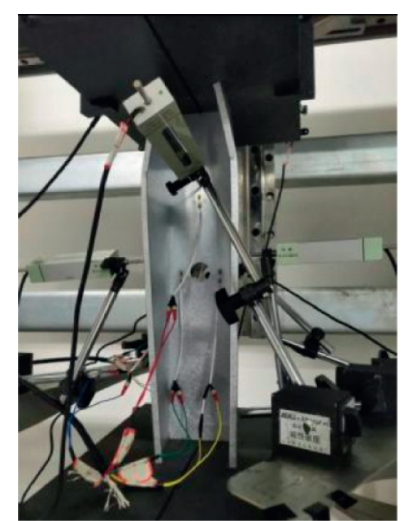

(d)

Figure 9: Buckling modes of the specimen C80-05-1H3-2. (a) Local buckling in the web. (b) Local buckling in flanges. (c) Distortional buckling. (d) Failure in interaction buckling.

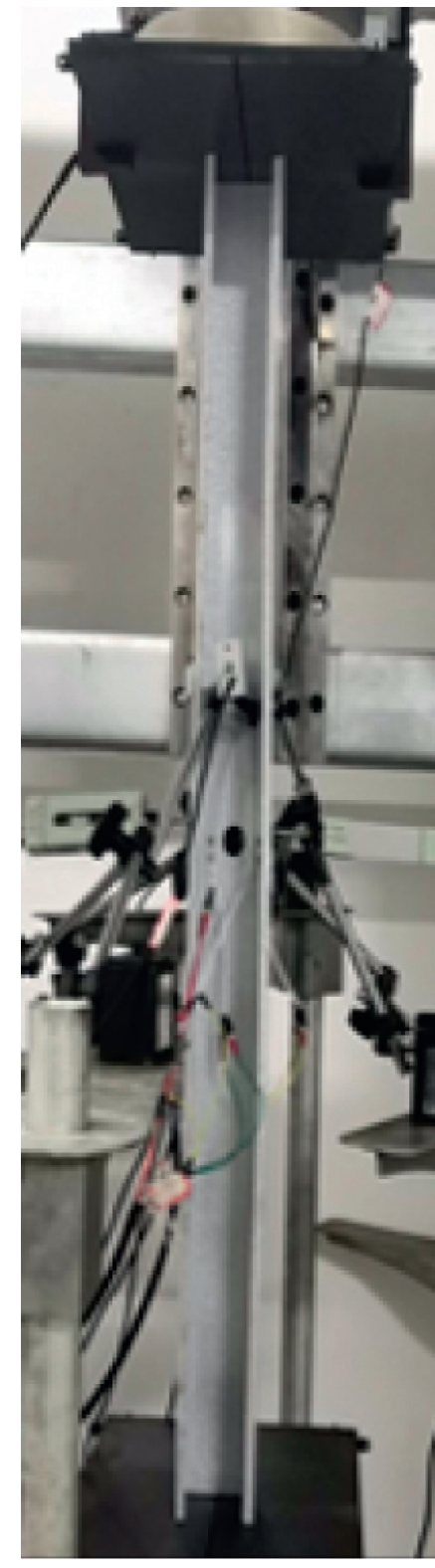

(a)

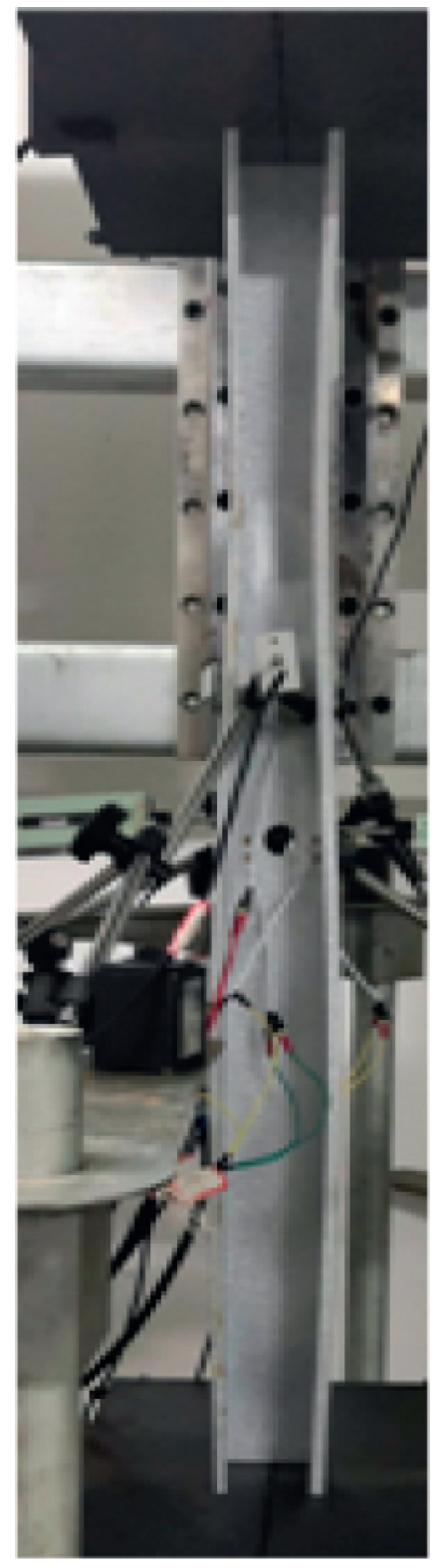

(b)

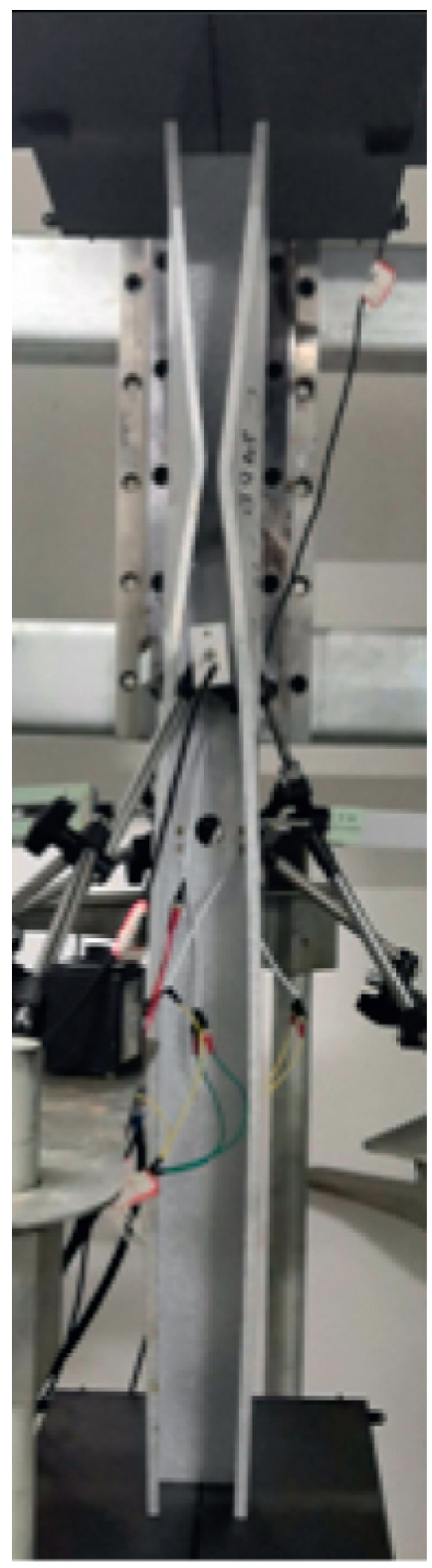

(c)

FIGURE 10: Buckling modes of the specimen C80-10-1H3-2. (a) Local buckling. (b) Distortional buckling. (c) Failure in interaction buckling. 


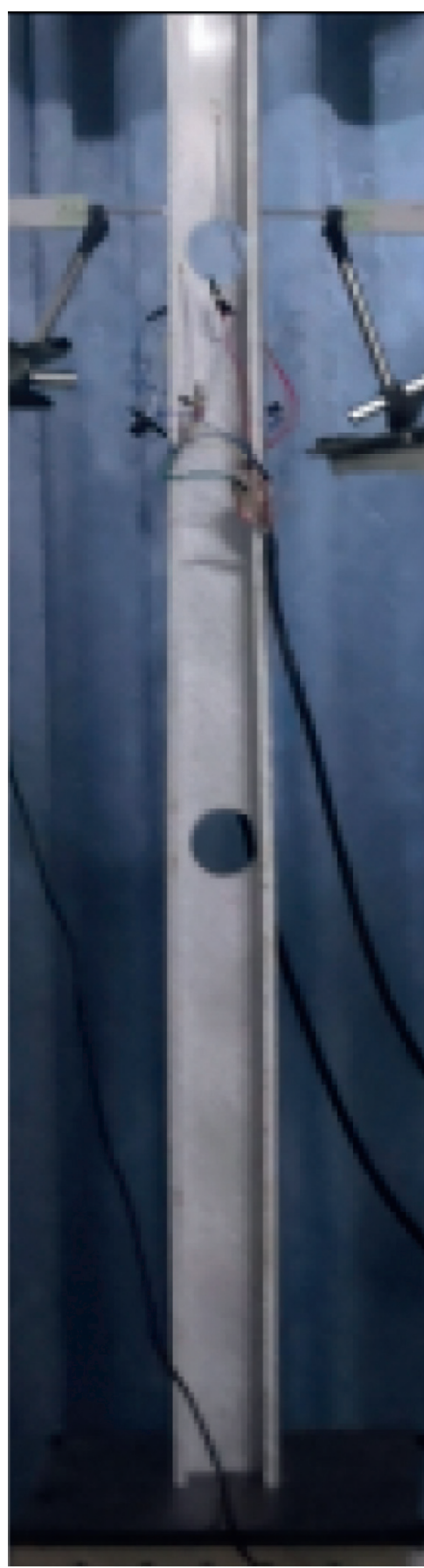

(a)

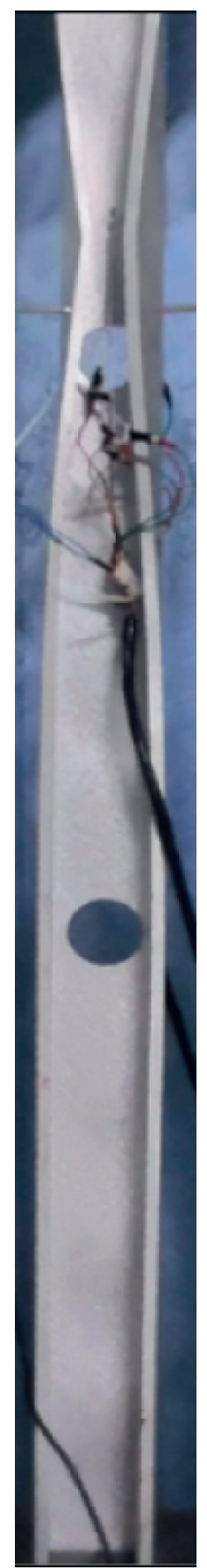

(b)

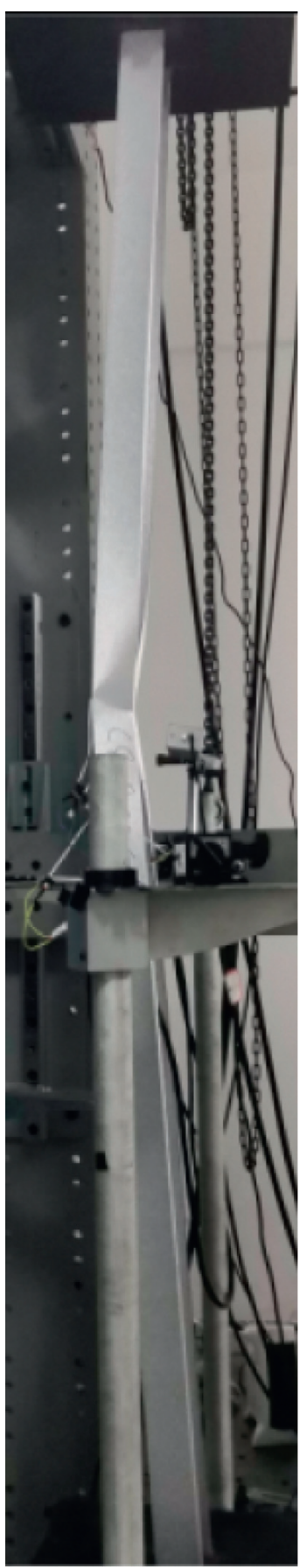

(c)

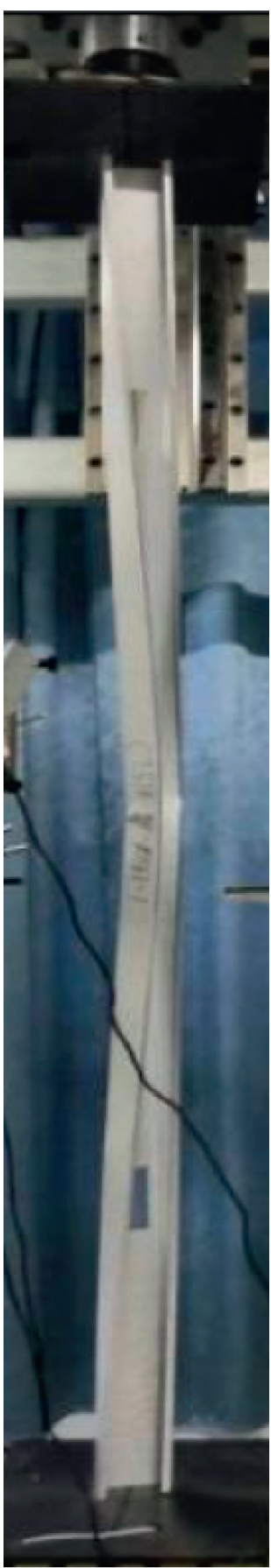

(d)

FIGURE 11: Buckling modes of specimens with a length of $2000 \mathrm{~mm}$. (a) Local buckling. (b) Distortional buckling. (c) Flexural buckling. (d) Flexural-torsional buckling.

coefficient which can be predicted according to the calculation method in Chinese code [18] and $\mu_{1}$ and $\mu_{2}$ are the reduced coefficients of the distortional buckling coefficients calculated by using formulas (1) and (2) which are obtained from Figures 18 and 19 for CFS lipped channel columns with a circular hole and multiple circular holes, respectively. 


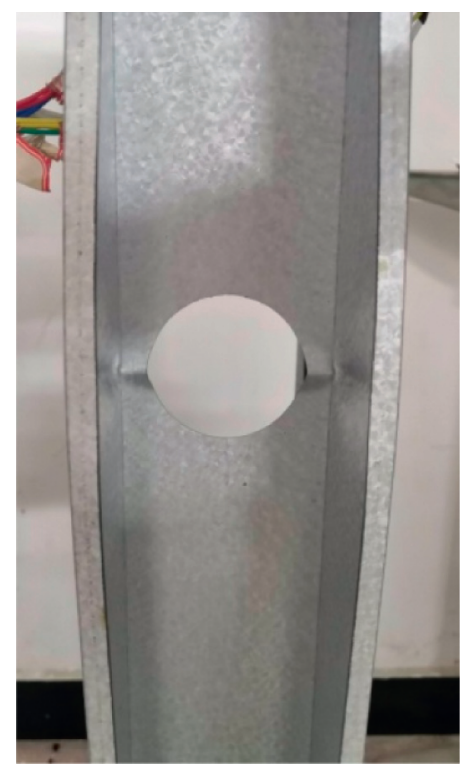

Figure 12: Plastic local buckling failure of plates adjacent to holes.

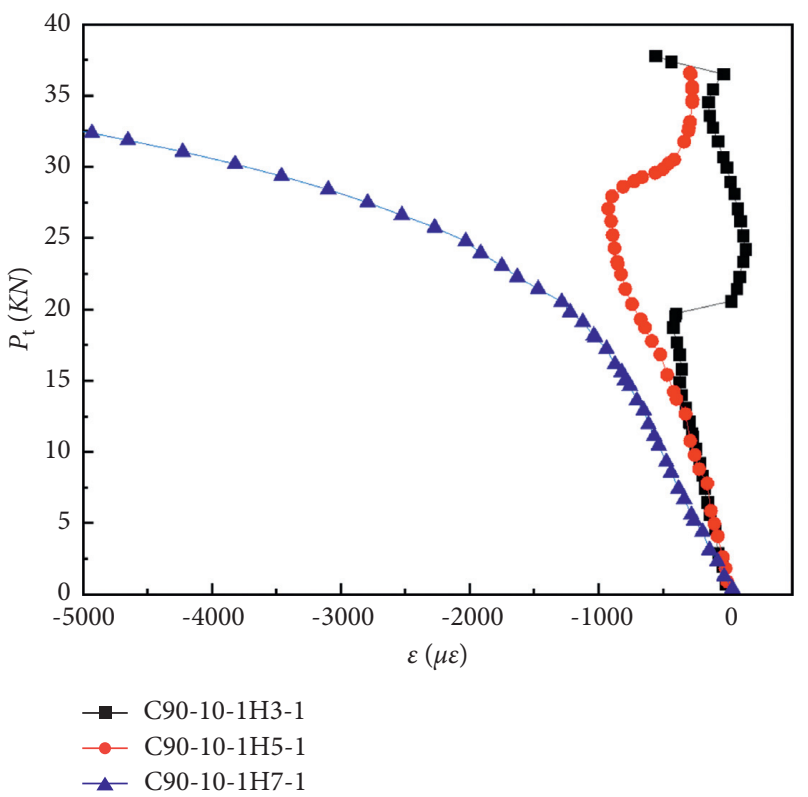

(a)

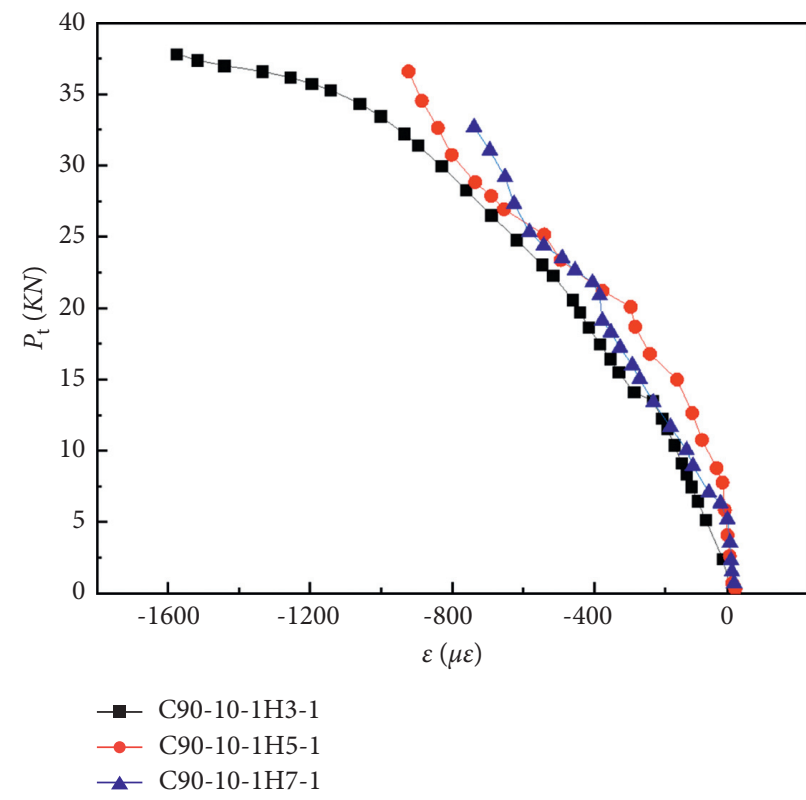

(b)

Figure 13: Load versus strain curves for section C90-10 with different circular hole sizes. (a) Strain gauge 4 . (b) Strain gauge 1. 

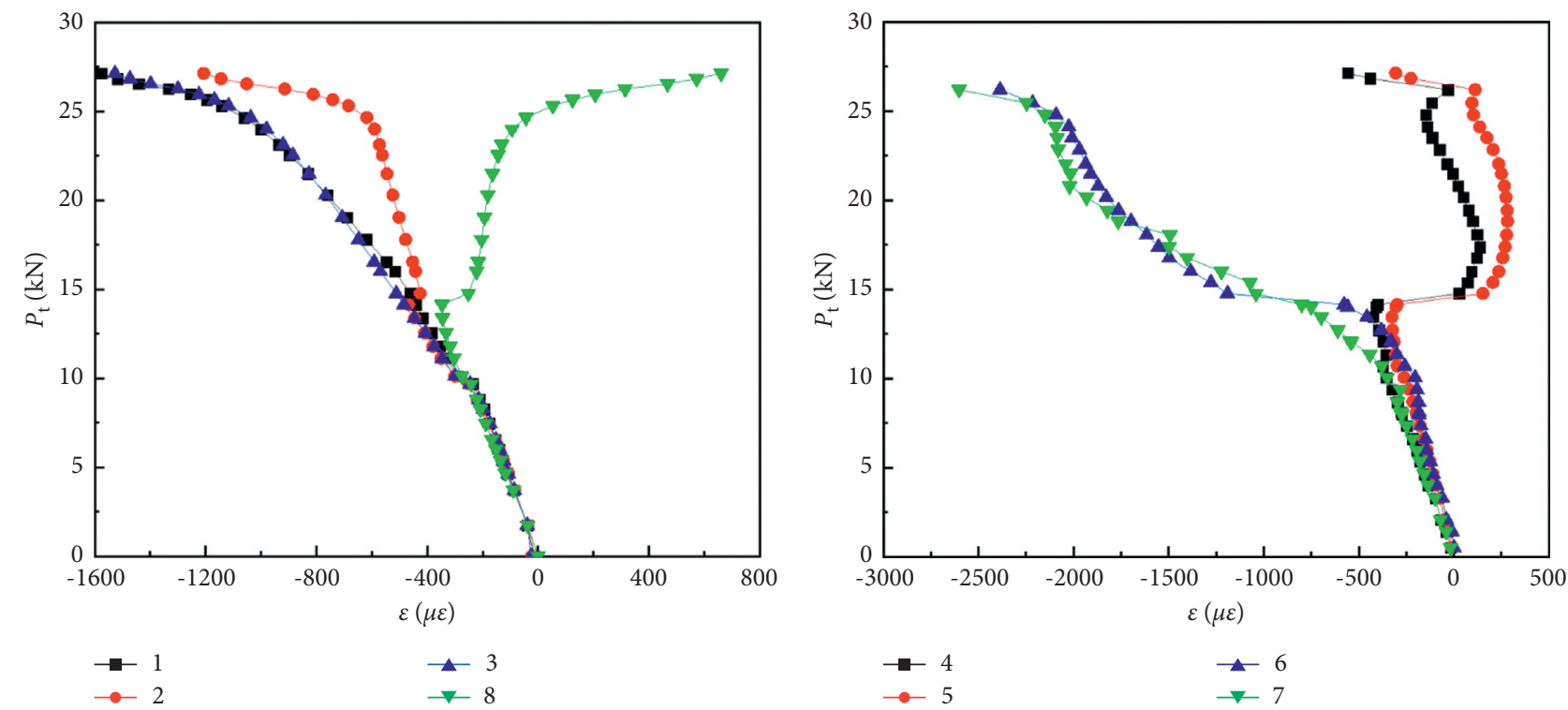

(a)

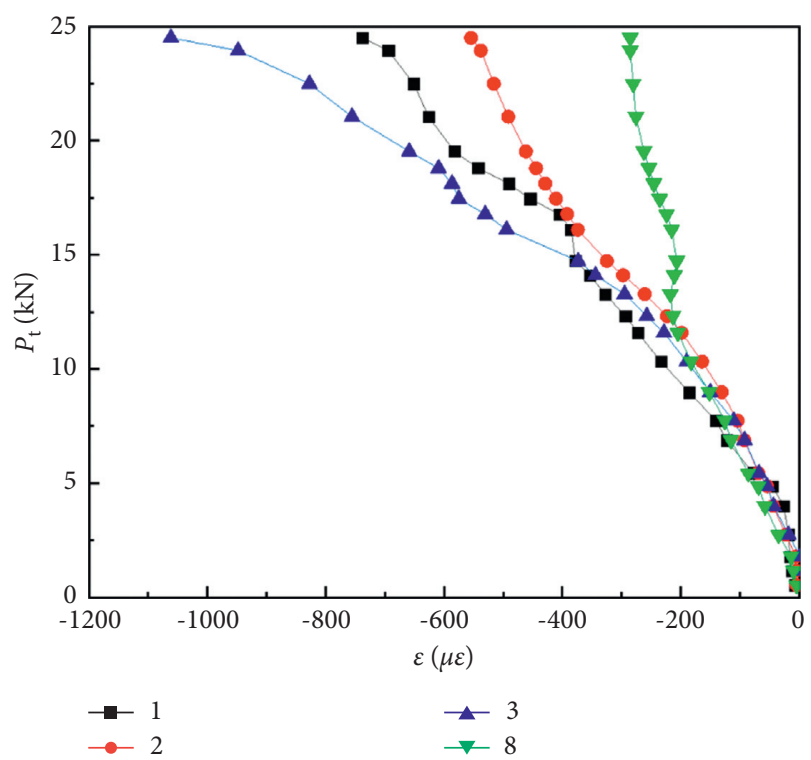

(c)

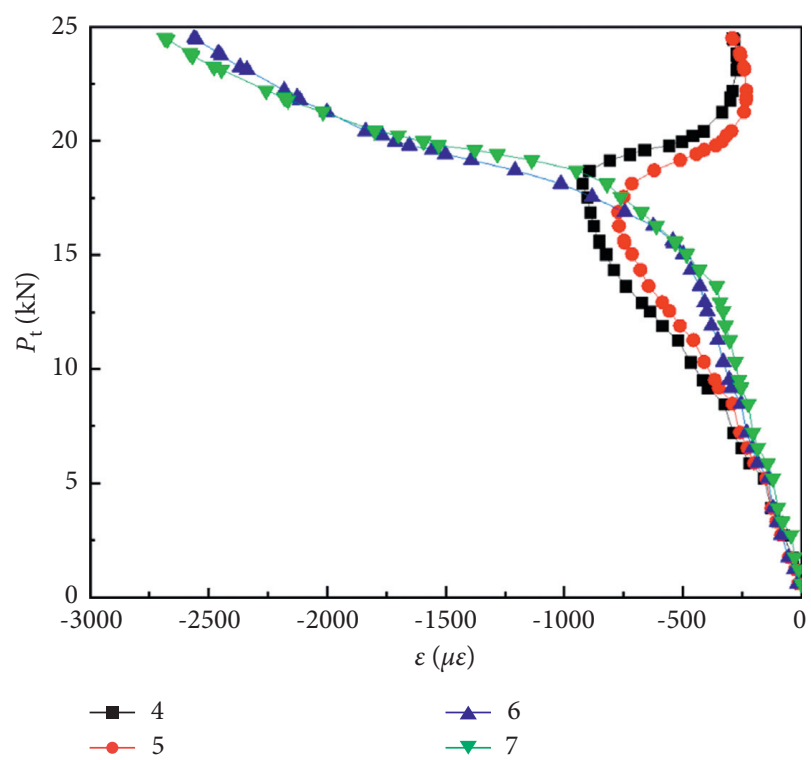

(d)

Figure 14: Load versus strain curve of section C80-10. (a) Specimen C80-10-1H3-1. (b) Specimen C80-10-1H3-1. (c) Specimen C80-101H7-1. (d) Specimen C80-10-1H7-1.

$$
\begin{aligned}
& \mu_{1}=1-0.012\left(\frac{d}{h}\right)-0.081\left(\frac{d}{h}\right)^{2} \\
& \mu_{2}=1-0.037\left(\frac{d}{h}\right)-0.164\left(\frac{d}{h}\right)^{2}
\end{aligned}
$$

\section{Modified Design Approach Based on Effective Method}

5.1. EWM-Based Design Approach. The ultimate strength of the CFS lipped channel column with circular holes under axial compression can be predicted using 


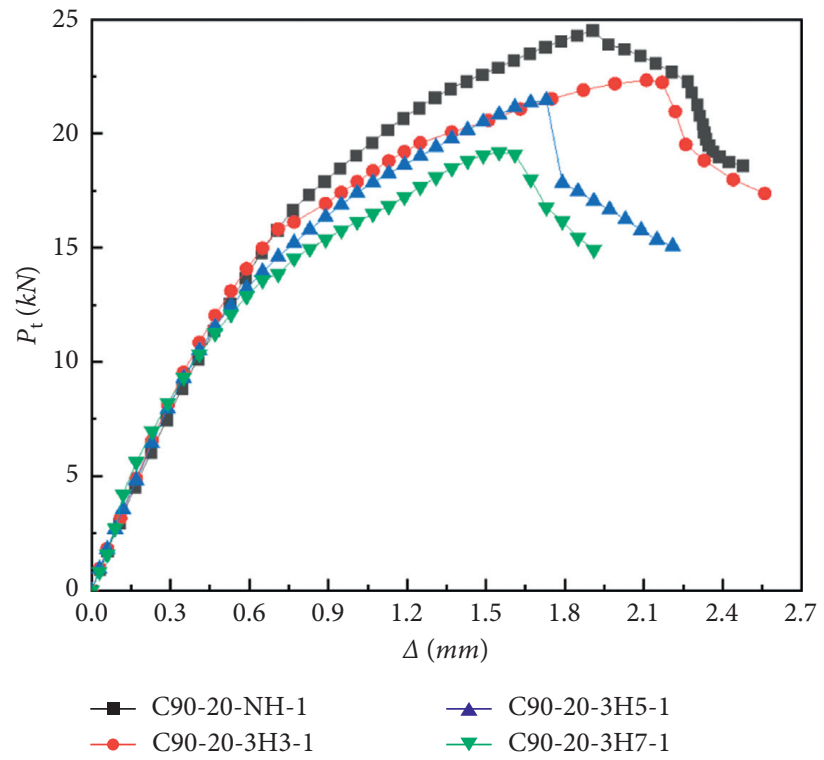

Figure 15: Load versus axial shorten displacement curves for section C90-20.

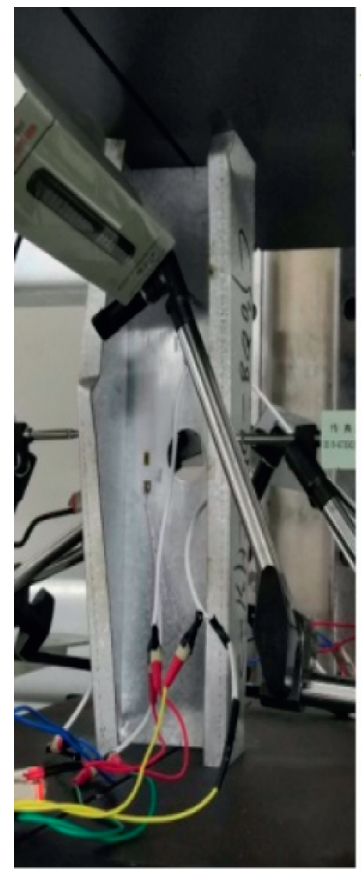

(a)

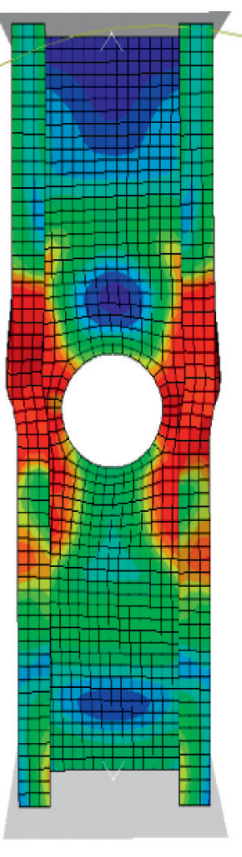

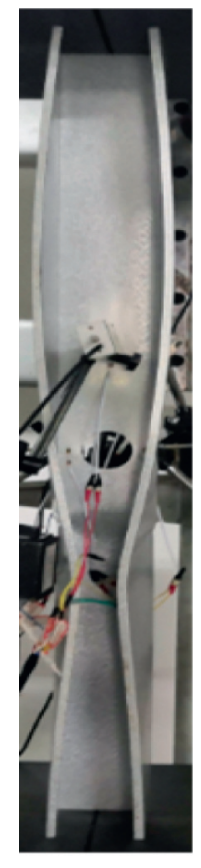

(b)

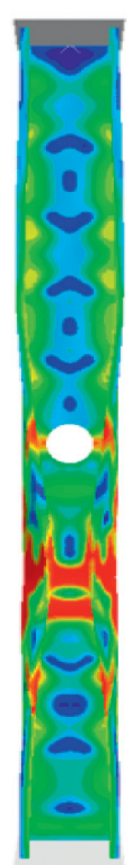

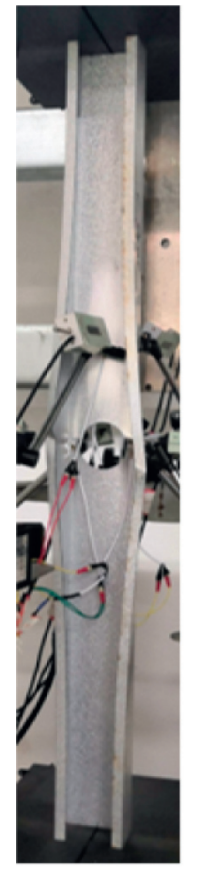

(c)

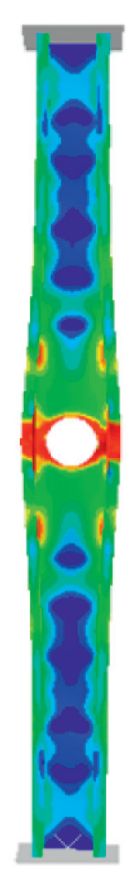

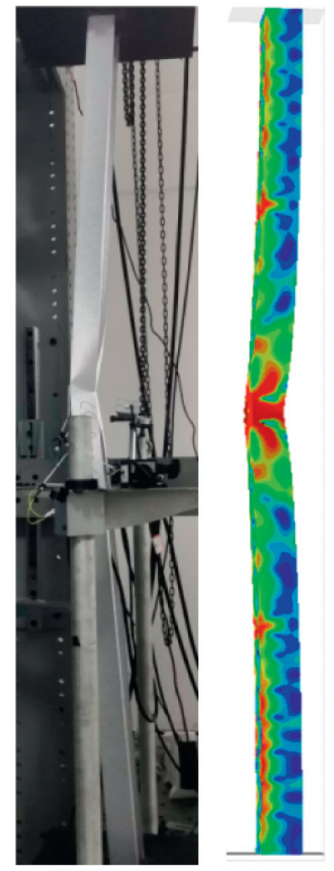

(d)

FIGURE 16: Comparison of failure modes of specimens between test and finite element analysis. (a) C90-05-1H7-2. (b) C90-10-1H5-2. (c) C90-10-1H7-2. (d) C90-20-3H7-2. 

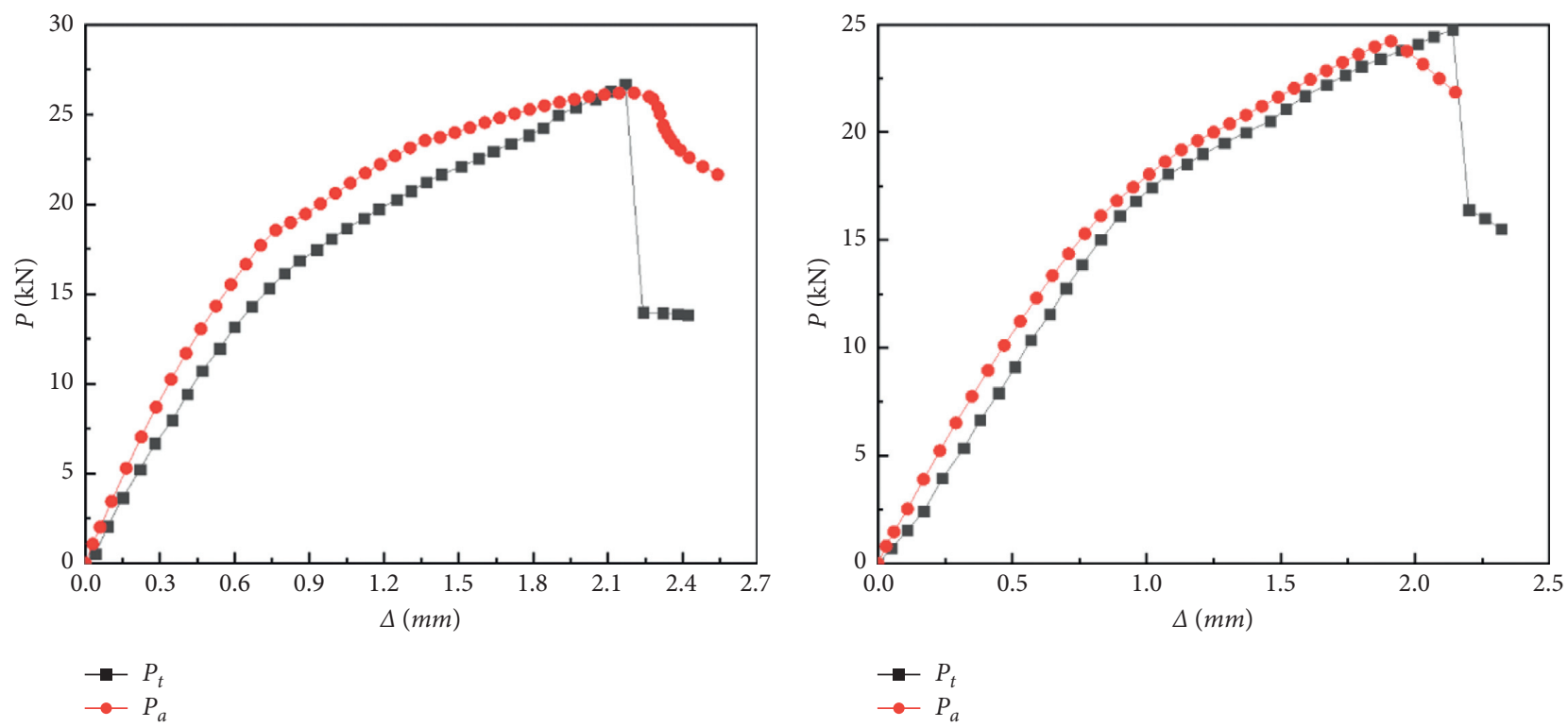

(a)

(b)

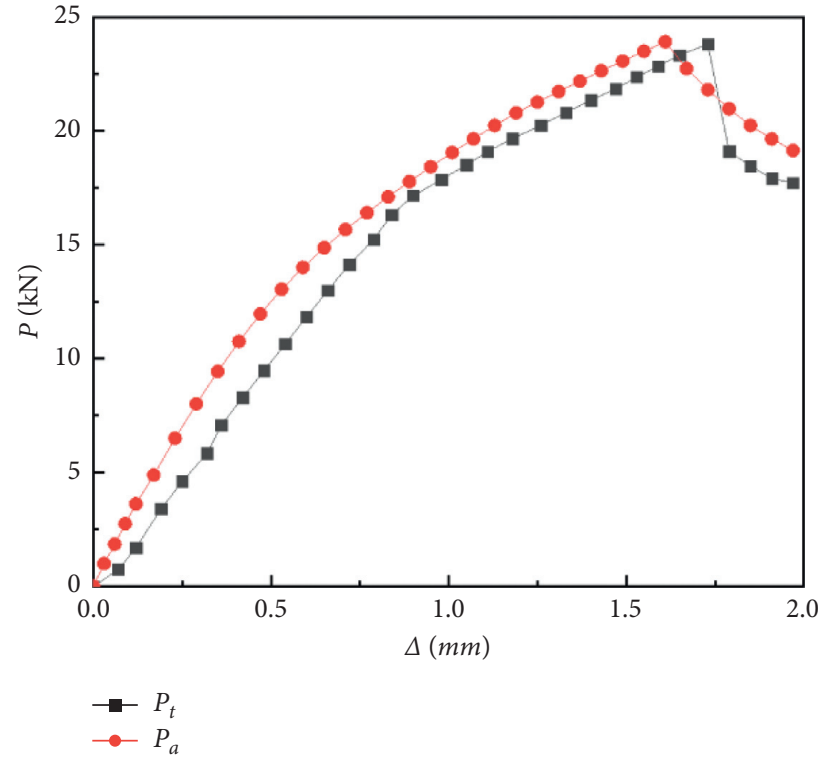

(c)

FIGURE 17: Comparison of load-axial shorten displacement curves of section C80-10 between test and FE analysis. (a) C80-10-2H3-2. (b) C80-10-2H5-2. (c) C80-10-2H7-2. 
TABLE 3: Comparison on ultimate loads between FE analysis results and predicted results.

\begin{tabular}{|c|c|c|c|c|c|c|c|c|c|c|c|}
\hline$L(\mathrm{~mm})$ & $h(\mathrm{~mm})$ & $b(\mathrm{~mm})$ & $a(\mathrm{~mm})$ & $t(\mathrm{~mm})$ & $f_{\mathrm{y}}(\mathrm{MPa})$ & Number of holes & Hole spacing $(\mathrm{mm})$ & $d(\mathrm{~mm})$ & $P_{\mathrm{a}}(\mathrm{kN})$ & $P_{\mathrm{c}}(\mathrm{kN})$ & $P_{\mathrm{a}} / P_{\mathrm{c}}$ \\
\hline 300 & 90 & 16 & 7.5 & 1 & 550 & 0 & 0 & 0 & 45.19 & 43.84 & 1.031 \\
\hline 300 & 90 & 16 & 7.5 & 1 & 550 & 1 & 0 & 27 & 45.09 & 43.29 & 1.042 \\
\hline 300 & 90 & 16 & 7.5 & 1 & 550 & 1 & 0 & 45 & 41.02 & 40.19 & 1.021 \\
\hline 300 & 90 & 16 & 7.5 & 1 & 550 & 1 & 0 & 63 & 36.13 & 33.95 & 1.064 \\
\hline 300 & 100 & 16 & 7.5 & 1 & 550 & 0 & 0 & 0 & 45.88 & 43.58 & 1.053 \\
\hline 300 & 100 & 16 & 7.5 & 1 & 550 & 1 & 0 & 30 & 44.34 & 43.02 & 1.031 \\
\hline 300 & 100 & 16 & 7.5 & 1 & 550 & 1 & 0 & 50 & 44.13 & 41.47 & 1.064 \\
\hline 300 & 100 & 16 & 7.5 & 1 & 550 & 1 & 0 & 70 & 37.43 & 36.68 & 1.020 \\
\hline 600 & 90 & 40 & 12 & 1 & 280 & 1 & 0 & 27 & 31.55 & 30.27 & 1.042 \\
\hline 600 & 90 & 40 & 12 & 1 & 280 & 1 & 0 & 63 & 20.75 & 18.56 & 1.118 \\
\hline 600 & 75 & 36 & 12 & 1.2 & 350 & 1 & 0 & 22.5 & 43.56 & 43.05 & 1.012 \\
\hline 600 & 75 & 36 & 12 & 1.2 & 350 & 1 & 0 & 52.5 & 27.09 & 24.50 & 1.106 \\
\hline 600 & 100 & 48 & 12 & 1 & 550 & 1 & 0 & 30 & 45.96 & 42.40 & 1.084 \\
\hline 600 & 100 & 48 & 12 & 1 & 550 & 1 & 0 & 70 & 32.52 & 29.58 & 1.099 \\
\hline 1000 & 90 & 40 & 12 & 1 & 280 & 0 & 0 & 0 & 36.14 & 33.86 & 1.067 \\
\hline 1000 & 90 & 40 & 12 & 1 & 280 & 1 & 0 & 27 & 35.64 & 33.56 & 1.062 \\
\hline 1000 & 90 & 40 & 12 & 1 & 280 & 1 & 0 & 45 & 33.96 & 31.20 & 1.088 \\
\hline 1000 & 90 & 40 & 12 & 1 & 280 & 1 & 0 & 63 & 29.90 & 28.12 & 1.063 \\
\hline 1000 & 75 & 38 & 8 & 1 & 550 & 0 & 0 & 0 & 42.78 & 40.59 & 1.054 \\
\hline 1000 & 75 & 38 & 8 & 1 & 550 & 1 & 0 & 22.5 & 42.37 & 40.19 & 1.054 \\
\hline 1000 & 75 & 38 & 8 & 1 & 550 & 1 & 0 & 37.5 & 40.19 & 37.52 & 1.071 \\
\hline 1000 & 75 & 38 & 8 & 1 & 550 & 1 & 0 & 52.5 & 36.63 & 34.35 & 1.066 \\
\hline 1500 & 90 & 40 & 12 & 1 & 280 & 0 & 0 & 0 & 33.96 & 31.09 & 1.092 \\
\hline 1500 & 90 & 40 & 12 & 1 & 280 & 3 & 500 & 27 & 33.07 & 30.69 & 1.078 \\
\hline 1500 & 90 & 40 & 12 & 1 & 280 & 3 & 500 & 45 & 30.89 & 28.23 & 1.094 \\
\hline 1500 & 90 & 40 & 12 & 1 & 280 & 3 & 500 & 63 & 27.84 & 26.15 & 1.065 \\
\hline 1500 & 76 & 38 & 8 & 1 & 550 & 0 & 0 & 0 & 34.95 & 32.27 & 1.083 \\
\hline 1500 & 76 & 38 & 8 & 1 & 550 & 3 & 500 & 22.5 & 34.46 & 31.88 & 1.081 \\
\hline 1500 & 76 & 38 & 8 & 1 & 550 & 3 & 500 & 37.5 & 31.19 & 28.93 & 1.078 \\
\hline 1500 & 76 & 38 & 8 & 1 & 550 & 3 & 500 & 52.5 & 27.52 & 25.34 & 1.086 \\
\hline 3000 & 90 & 40 & 12 & 1 & 280 & 6 & 500 & 26.7 & 9.21 & 9.04 & 1.019 \\
\hline 3000 & 90 & 40 & 12 & 1 & 280 & 6 & 500 & 62.3 & 7.87 & 7.86 & 1.001 \\
\hline 3000 & 75 & 36 & 12 & 1.2 & 350 & 6 & 500 & 21 & 7.63 & 7.05 & 1.082 \\
\hline 3000 & 75 & 36 & 12 & 1.2 & 350 & 6 & 500 & 49 & 6.67 & 6.83 & 0.977 \\
\hline 3000 & 100 & 48 & 12 & 1 & 550 & 6 & 500 & 30 & 13.66 & 13.24 & 1.032 \\
\hline 3000 & 100 & 48 & 12 & 1 & 550 & 6 & 500 & 70 & 12.61 & 12.84 & 0.982 \\
\hline \multicolumn{11}{|c|}{$\begin{array}{c}\text { Average } \\
\text { Standard deviation } \\
\text { Coefficient of variation }\end{array}$} & $\begin{array}{l}1.0614 \\
0.0286 \\
0.0243\end{array}$ \\
\hline
\end{tabular}

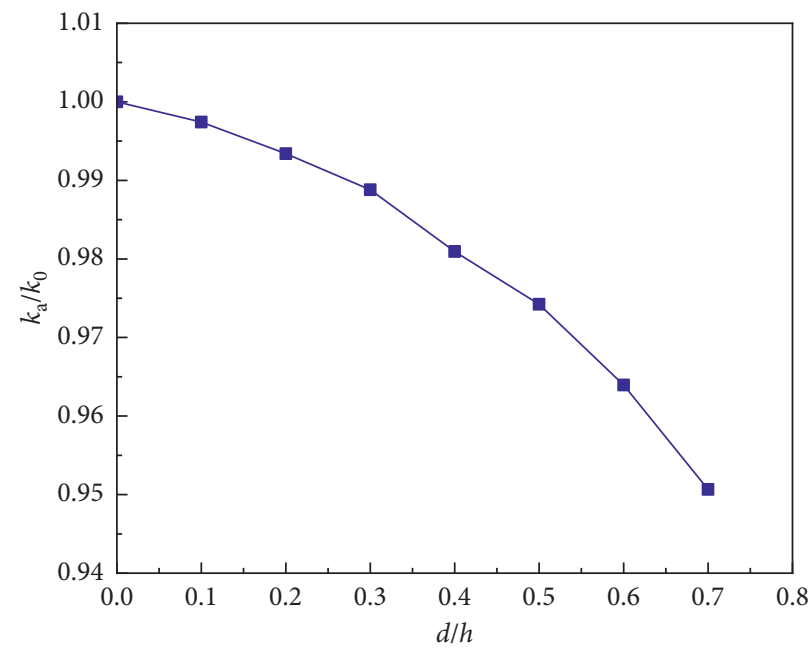

FIgURE 18: Distortional buckling coefficients of lipped channel columns with a circular hole. 


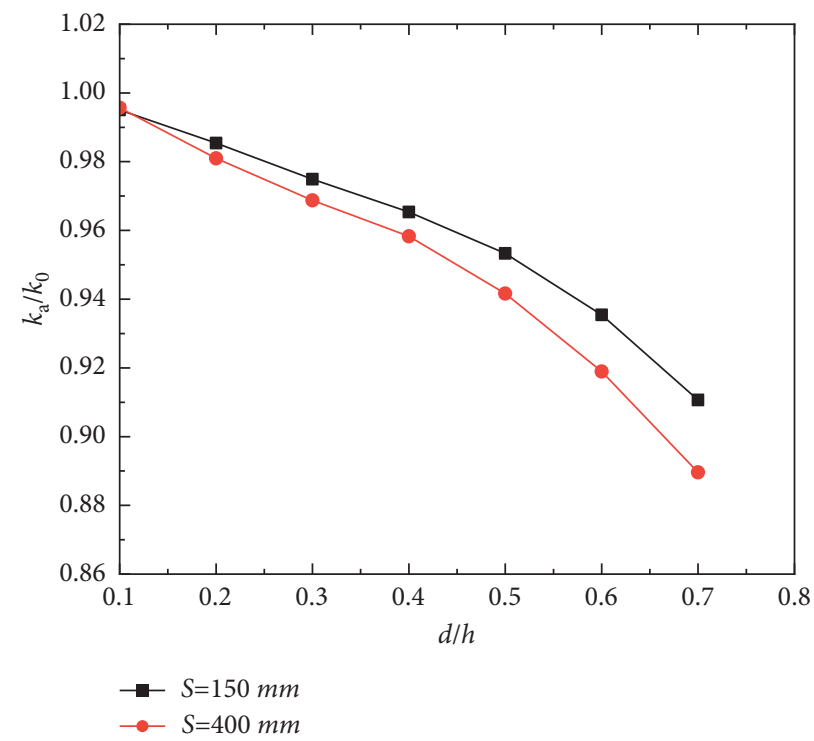

FIGURE 19: Distortional buckling coefficient of columns with three circular holes in different hole spacings.

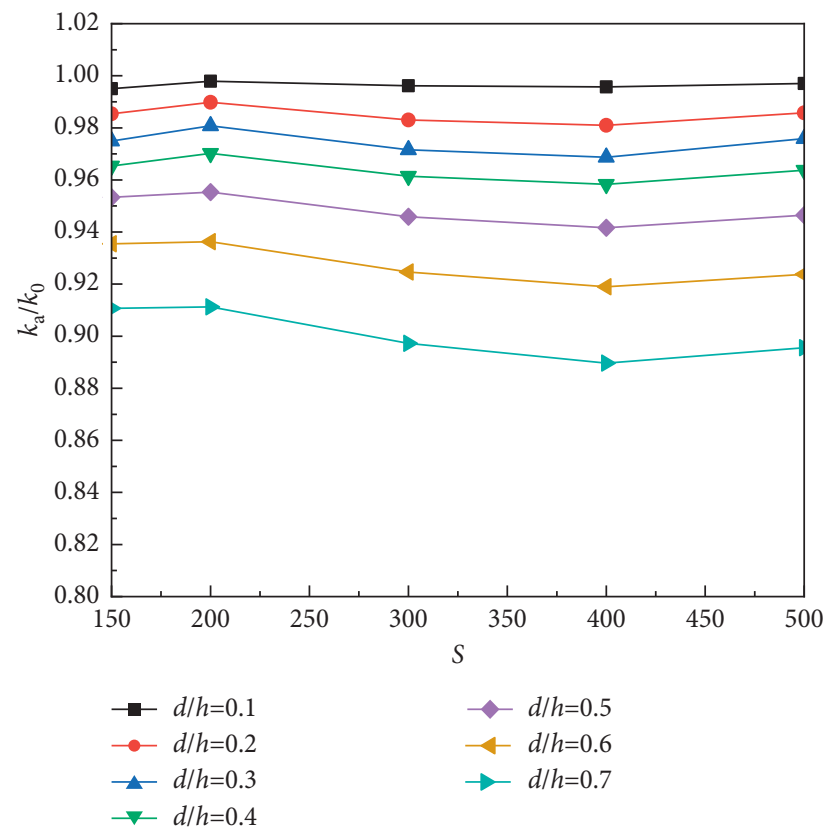

FIGURE 20: Distortional buckling coefficient of columns with different spacings and diameter of circular holes. 


$$
N=\varphi A_{\mathrm{e}} f_{\mathrm{y}},
$$

where $\varphi$ is the global buckling coefficient of the CFS axial compression member and $A_{\mathrm{e}}$ is the effective cross-sectional area of the axial compression column with circular holes. $A_{\mathrm{e}}=b_{\mathrm{e}} t$, where $b_{\mathrm{e}}$ is the effective width of the compression plate and can be calculated by using the following formula:

$$
\frac{b_{\mathrm{e}}}{t}= \begin{cases}\frac{b_{\mathrm{c}}}{t}, & \frac{b}{t} \leq 18 \alpha \rho, \\ \left(\sqrt{\frac{21.8 \alpha \rho}{b / t}}-0.1\right) \frac{b_{\mathrm{c}}}{t}, & 18 \alpha \rho<\frac{b}{t}<38 \alpha \rho, \\ \frac{25 \alpha \rho}{b / t} \frac{b_{c}}{t}, & \frac{b}{t} \geq 38 \alpha \rho .\end{cases}
$$

For the axial compression column, $b_{\mathrm{c}}=b, \alpha=1$, and $\rho=\sqrt{235 k / \varphi f_{\mathrm{y}}}, k$ is the buckling coefficient of the axial compression plate. The reduction of the buckling coefficient should be considered when formula (4) is used to predict the effective width of the CFS lipped channel column with circular holes under axial compression. The reduced local buckling coefficient and the effective width of the web considering the influence of the circular holes should be calculated according to the proposed method in reference [23]. For lipped channel columns with single circular hole and multiple circular holes, the reduced distortional buckling coefficient of the flange should be predicted by using formulas (1) and (2), respectively.

\subsection{Comparison of Ultimate Strengths with Test and FEA Data.} The ultimate strengths $\left(P_{\mathrm{c}}\right)$ of all specimens calculated by using the modified EWM design approach are listed in Table 2. The average ratios of test results to the calculated capacities $P_{\mathrm{t}} / P_{\mathrm{c}}$ is 1.0172 with the coefficient of variation of 0.019 . The calculated ultimate strengths were compared with FE results, as shown in Table 3 . The average ratios of $P_{\mathrm{a}} / P_{\mathrm{c}}$ is 1.0614 with the coefficient of variation of 0.0243 . The comparisons show that the proposed EWM-based design method is applicable and feasible to predict the ultimate capacities of CFS lipped channel columns with circular holes under axial compression.

\section{Conclusions}

This paper presents the results of an experimental study of 54 CFS lipped channel columns with and without circular holes in the web under axial compression. The interaction of local buckling and distortional buckling were observed for short and intermediate columns. The slender columns were controlled by the interaction of local buckling, distortional buckling, and flexural buckling or flexural-torsional buckling. The presence of circular holes resulted in the ultimate loads lower than that of columns without circular holes. The circular holes caused a decreasingly larger value as the diameter of circular hole increased.
The finite element model was developed and validated by test results about failure modes and failure loads. The validated finite element model was further used to simulate the failure loads of CFS lipped channel columns with different circular hole sizes and lengths. The finite element results also show that the ultimate load decreases with the increase in the diameter of the circular hole. Based on elastic distortional buckling analysis, the reduction formulas to predict the distortional buckling coefficient of CFS lipped channel columns with circular holes under axial compression were developed.

Compared with the test results and finite element analysis results, the proposed EWM-based design method provides reasonably good agreement for CFS lipped channel columns with circular holes under axial compression.

\section{Data Availability}

The data used to support the findings of this study are available from the corresponding author upon request.

\section{Conflicts of Interest}

The authors declare that there are no conflicts of interest regarding the publication of this paper.

\section{Acknowledgments}

This work was financially supported by the National Natural Science Foundation Projects of China, grant number 51868049.

\section{References}

[1] R. A. O. Colberg, "The load carrying capacity of perforated cold-formed steel columns," Thesis, Cornell University, NY, USA, 1981.

[2] C. D. Moen and B. W. Schafer, "Experiments on cold-formed steel columns with holes," Thin-Walled Structures, vol. 46, no. 10, pp. 1164-1182, 2008.

[3] B. He and G. Zhao, "Analysis on buckling behavior of coldformed lipped channel with perforated web," J. Xi'an Ins. Metal.\& Const. Eng.vol. 21, pp. 1-9, 1989, (In Chinese).

[4] Y. Yao, Z. Wu, B. Cheng, and J. B. Deng, "Experimental investigation into axial compressive behavior of cold-formed thin-walled steel columns with lipped channel and openings," J. South China Univ. Tech. (Natural Science Edition), vol. 39, pp. 61-67, 2011.

[5] M. P. Kulatunga, M. Macdonald, J. Rhodes, and D. K. Harrison, "Load capacity of cold-formed column members of lipped channel cross-section with perforations subjected to compression loading - Part I: FE simulation and test results," Thin-Walled Structures, vol. 80, pp. 1-12, 2014.

[6] M. P. Kulatunga and M. Macdonald, "Investigation of coldformed steel structural members with perforations of different arrangements subjected to compression loading," ThinWalled Structures, vol. 67, pp. 78-87, 2013.

[7] L. Xu, Y. Shi, and S. Yang, "Compressive strength of coldformed steel c-shape columns with slotted holes," in Proceedings of the Twenty-second International Specialty Conference on Cold-Formed Steel Structures: Recent Research and Developments in Cold-Formed Steel Design and Construction, 
pp. 157-170, University of Missouri-Rolla, Saint Louis, USA, November 2014.

[8] D. Zheng and S. Yu, "Analysis of distortional buckling performance of cold-formed lipped-channel with perforations," Pro. Steel Build. Struct.vol. 12, pp. 32-37, 2010.

[9] Y. Guo and X. Yao, "Distortional buckling behavior and design method of cold-formed steel lipped channel with rectangular holes under axial compression," Mathematical Biosciences and Engineering, vol. 18, no. 5, pp. 6239-6261, 2021.

[10] M. L. Dung, P. T. Chung, J. L. Liu, and C. L. Pan, "The compressive strength of slender C-shaped cold-formed steel members with web openings," Int. J. Steel Struct.vol. 9, pp. 231-240, 2009.

[11] C. D. Moen and B. W. Schafer, "Direct strength method for design of cold-formed steel columns with holes," J. Struct. Eng., ASCE, vol. 137, pp. 559-570, 2016.

[12] Z. Yao and K. J. R. Rasmussen, "Perforated cold-formed steel members in compression. II: Design," Journal of Structural Engineering, vol. 143, Article ID 04016227, 2017.

[13] C. D. Moen and B. W. Schafer, "Elastic buckling of thin plates with holes in compression or bending," Thin-Walled Structures, vol. 47, no. 12, pp. 1597-1607, 2009.

[14] C. D. Moen and B. W. Schafer, "Elastic buckling of coldformed steel columns and beams with holes," Engineering Structures, vol. 31, no. 12, pp. 2812-2824, 2009.

[15] J. Zhou and S. Yu, "Equiavalentcal calculation of buckling stress for cold-formed thin wall perforated channel columns," Industrial Construction, vol. 130, pp. 27-31, 2010.

[16] X. Yao, Y. Guo, Y. Liu, J. Su, and Y. Hu, "Analysis on distortional buckling of cold-formed thin-walled steel lipped channel steel members with web openings under axial compression," Industrial Construction, vol. 50, pp. 170-177, 2020.

[17] American Iron and Steel Institute AISI S100-16, North American Specification for the Design of Cold-Formed Steel Structural Members, Canadian Standards Association, Toronto, Canada, 2016.

[18] Ministry of Housing, Ministry of Housing and Urban-Rural Development of the People's Republic of China, GB50018-2002, Technical Code for Cold-Formed Thin-Walled Steel Structures, Chinese Planning Press, Beijing, China, 2002.

[19] General Administration of Quality Supervision, Inspection and Quarantine of the People's Republic of China, GB/T 228.12010, Tensile Tests of Metallic Materials Part 1: Test Methods at Room Temperature, China Standard Press, Beijing, China, 2011.

[20] X. Yao, Buckling Behavior and Effective Width Method of Perforated Cold-Formed Steel Columns under Axial Compression (Research Report), Nanchang Institute of Technology, Nanchang, China, 2020.

[21] X. Yao, "Experimental investigation and load capacity of slender cold-formed lipped channel sections with holes in compression," Advances in Civil Engineering, vol. 2021, Article ID 665809, 18 pages, 2021.

[22] ABAQUS, ABAQUS/Standard User's Manual Volumes I-III and ABAQUS CAE Manual, Dassault Systemes Simulia Corporation, Johnston, Rhode Island, USA, 2014.

[23] Y. Guo and X. Yao, "Buckling behavior and effective width design method for thin plates with holes under stress gradient," Mathematical Problems in Engineering, vol. 2021, Article ID 5550749, 20 pages, 2021. 